\title{
Ordinary Artists: From Paradox to Paradigm?
}

Variations on a Concept and its Outcomes

Artistes ordinaires: du paradoxe au paradigme? Variations autour d'un concept et de ses prolongements

Artistas ordinarios : ¿ de la paradoja al paradigma ? Variaciones en torno a un concepto y sus ramificaciones

\section{Marc Perrenoud and Géraldine Bois}

Translator. Jasmin Smith and Delaina Haslam

\section{Q OpenEdition}

\section{Electronic version}

URL: http://journals.openedition.org/bssg/171

DOI: $10.4000 /$ bssg. 171

ISSN: 2490-9424

\section{Publisher}

Presses universitaires de Vincennes

\section{Electronic reference}

Marc Perrenoud and Géraldine Bois, "Ordinary Artists: From Paradox to Paradigm?", Biens Symboliques / Symbolic Goods [Online], 1 | 2017, Online since 15 October 2017, connection on 04 March 2021. URL: http://journals.openedition.org/bssg/171 ; DOI: https://doi.org/10.4000/bssg. 171 

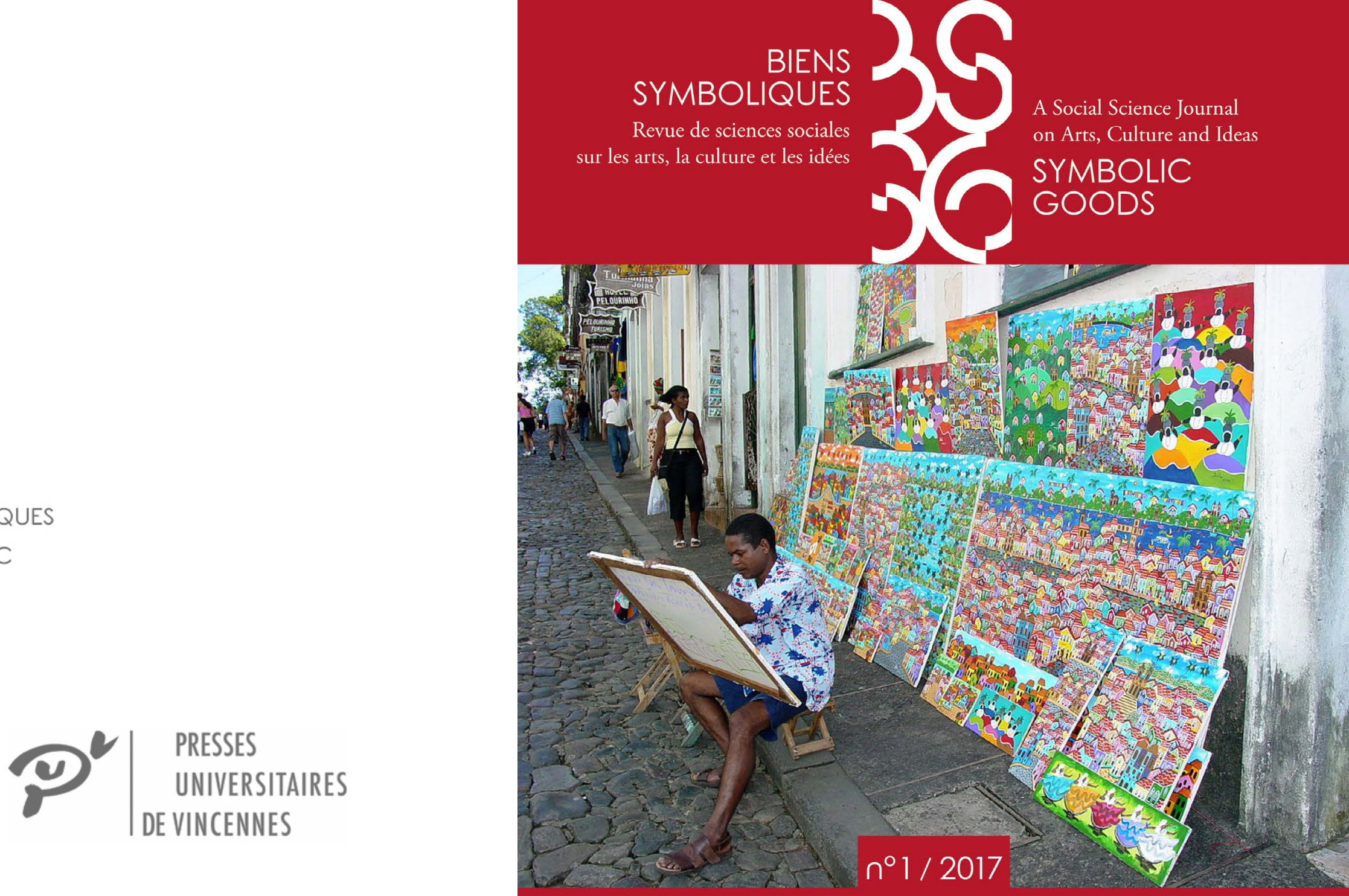

\section{Artistes ordinaires \\ Ordinary Artists}




\section{Artistes ordinaires: Ordinary Artists: \\ du paradoxe au paradigme? From Paradox to Paradigm? \\ Variations autour d'un concept Variations on a Concept et de ses prolongements ${ }^{1}$ and its Outcomes ${ }^{1}$}

Marc Perrenoud | Géraldine Bois

traduction | translation

Jasmin Smith

corrigée par | revised by

Delaina Haslam

1 Le présent article a bénéficié de la relecture aussi attentive que constructive de Séverine Sofio et Wenceslas Lizé, qui ont aussi accompagné l'édition de tout le dossier thématique : qu'ils en soient chaleureusement remerciés. Nous tenons aussi à témoigner notre gratitude à Isabelle Gouarné (pour

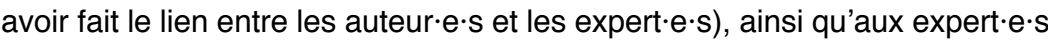
et aux traducteurs et traductrices.

1 We wish to sincerely thank Séverine Sofio and Wenceslas Lizé for their thorough reading and all the improvement suggestions they've made for this article, and for managing the whole dossier. We are also very grateful to Isabelle Gouarné (who acted as a liaison between the authors and the experts), as well as to the experts and the translators who worked on this dossier. 


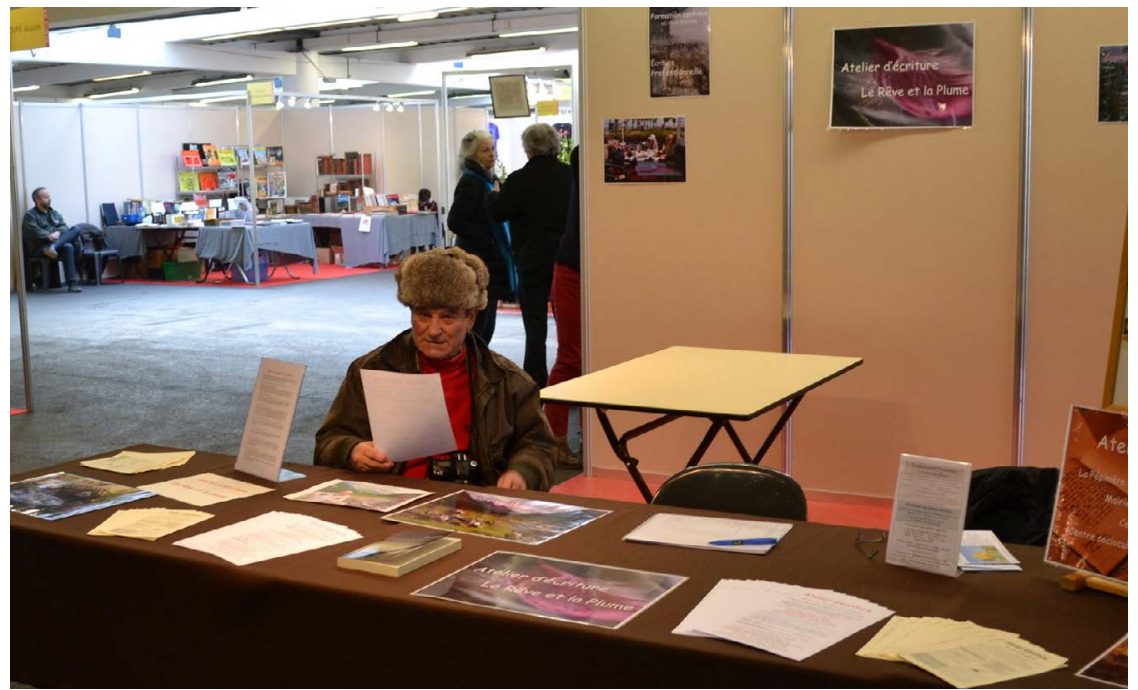

Un salon du livre régiona

A regional book fair

Source :

https://commons.wikimedia.org/wiki/File:Atelier_d\%27\%C3\%A9criture_Le_R\%C3\%AAve_et_la_plume_-_Salon_Le_Livre_en_B\%C3\%A9arn_2015.JPG

(C) Wikimedia Commons (CC)

Le premier dossier thématique de Biens symboliques / Symbolic Goods porte sur les « artistes ordinaires ${ }^{2}$ ». Cette notion est dérivée de celle mobilisée par Marc Perrenoud qui a caractérisé la population des « musiciens ordinaires » en France au tournant du siècle (Perrenoud 2007), en s'inspirant

2 Cette expression désigne autant - et sans doute plus, si l'on considère la situation des artistes femmes (Pasquier 1983 ; Ravet 2003 ; Buscatto 2007) - des femmes que des hommes. Nous avons cependant décidé d'employer uniquement la forme masculine tout au long de cet article par souci de lisibilité.
The first themed dossier of Biens symboliques / Symbolic Goods focuses on "ordinary artists." 2 This notion is derived from that put forward by Marc Perrenoud, who characterized the population of "ordinary musicians" in France at the turn of the twenty-first century (Perrenoud 2007), drawing explicitly from the "dance musicians" whom Howard S. Becker studied in the 1960s (Becker 1963). Becker and Robert R. Faulkner

2 Our use of this label applies to both men and women, although it is undoubtedly particularly relevant to the situation of women (Pasquier 1983; Ravet 2003; Buscatto 2007). 
explicitement des «musiciens de danse » dont Howard S. Becker avait publié l'étude il y a une cinquantaine d'années (Becker 1963) ; Becker et Robert R. Faulkner ont ensuite emprunté à leur tour l'expression « musiciens ordinaires» à Perrenoud dans un ouvrage récent (Faulkner \& Becker 2011). Par ailleurs, les travaux de sociologues francophones autour des modes mineurs ou partiels de la reconnaissance artistique, des formes « inachevées » de la consécration ${ }^{3}$, se sont multipliés ces dernières années à propos de disciplines artistiques variées (entre autres : Poliak 2006 ; Sinigaglia 2007 ; Dubois et al. 2009 ; Sorignet 2010 ; Bajard \& Perrenoud 2013 ; Cardon \& Pilmis 2013 ; Bois 2014). À l'image de ces publications récentes, les articles du dossier ne sont pas centrés exclusivement sur le domaine de la musique mais font travailler cette catégorie de "l'ordinaire » à partir de plusieurs disciplines et secteurs (audiovisuel, théâtre, musique, danse, arts plastiques et graphiques). Ainsi, seule la réflexion d'Adrien Pégourdie est exclusivement centrée sur des musiciens ; la contribution de Serge Katz porte sur une profession qui peut s'exercer dans deux secteurs différents : les comédiens dans l'audiovisuel et le spectacle vivant ; l'article de Jérémy Sinigaglia concerne tous les arts du spectacle et celui d'Audrey Millet, qui donne au dossier sa profondeur historique, explore les marges des mondes de l'art avec une étude des dessinateurs travaillant pour les manufactures du luxe au $\mathrm{XVIII}^{\mathrm{e}}$ siècle. Un dernier article - celui de Pierre

3 La reconnaissance peut se décliner en plusieurs degrés, comme IDindiquent les adjectifs « mineurs » et « partiels ». La notion de consécration renvoie quant à elle à un " haut degré de reconnaissance » et enferme une connotation de sacralité (Denis 2010) qui l'oppose donc à l'« ordinaire ». then borrowed the expression "ordinary musicians" from Perrenoud in a recent book (Faulkner \& Becker 2009). At the same time, the work of French-speaking sociologists on minor or partial forms of artistic recognition, including "incomplete" forms of consecration ${ }^{3}$, has expanded a great deal over the last few years regarding various artistic disciplines (see Poliak 2006; Sinigaglia 2007; Dubois et al. 2009; Sorignet 2010; Bajard \& Perrenoud 2013; Cardon \& Pilmis 2013; Bois 2014, among others). Like these recent publications, this dossier's articles are not focused exclusively on music but rather discuss this qualification of "ordinary" as it applies to various disciplines and sectors (audiovisual media, theatre, music, dance, graphic and plastic arts). Therefore, only Adrien Pégourdie deals exclusively with musicians in his paper; Serge Katz studies a profession that straddles two different sectors-stage and screen actors; Jérémy Sinigaglia looks at all performing arts; and Audrey Millet, whose article gives the dossier its historic depth, explores the fringes of the art world with a study of draughtsmen working for luxury manufacturers in the eighteenth century. One last article, written by Pierre Bataille, occupies a particular position in this dossier as well as being essential to the reflection concerned: through the case of normaliens teaching in schools and colleges, ${ }^{4}$ it proposes an extension of the notion of "ordinary artists" to the spheres of intellectual production, that is to say to another

3 Recognition can happen to varying degrees, as indicated by adjectives such as "minor" and "partial." The notion of "consecration" refers to a "high degree of recognition," which puts it in direct opposition with the "ordinary."

4 In France, normaliens are graduates of the Écoles normales supérieuresprestigious higher education establishments that only admit students based on a very selective examination process. 
Bataille - occupe une position distincte dans ce dossier tout en étant essentiel à la réflexion qui y est menée : à travers le cas de normaliens enseignant dans le secondaire ${ }^{4}$, il permet de tester la pertinence d'un prolongement de la notion d'« ordinaire » aux espaces de la production intellectuelle, donc à une autre grande catégorie d'acteurs producteurs de biens symboliques. Plus précisément, ce texte permet de voir dans quelle mesure on peut observer dans le domaine de l'enseignement - profession pourtant très institutionnalisée et caractérisée par des carrières beaucoup plus prévisibles que dans les univers artistiques - des parcours de reconnaissance professionnelle et des manières de les vivre proches de ceux

des artistes.

Tous les artistes étudiés dans ce numéro ont en commun de n'être ni riches (relativement au marché professionnel où ils exercent) ni célèbres. Ce ne sont ni des «stars », ni des «grands » artistes, très reconnus et consacrés. Cette situation concerne la grande majorité des artistes et demeure pourtant peu étudiée. Cette sociologie de la banalité, qui s'intéresse au travail artistique y compris dans ce qu'il peut avoir d'ordinaire, n'a longtemps connu que peu de représentants. À cet égard, les travaux de Cynthia White et Harrison $C$. White ainsi que ceux de Raymonde Moulin sur les carrières de peintres et le marché de l'art (mais aussi, pour Moulin, sur le marché des chromos) peuvent apparaître comme précurseurs (White \& White 1965; Moulin 1967). À la même époque, le travail de

4 En France, les « normaliens 》 sont les diplômés des écoles normales supérieures, établissements d'enseignement supérieur prestigieux, accessibles par le biais d'un concours très sélectif. large category of actors producing symbolic goods. More precisely, this paper shows how career paths, and access to and experiences of professional recognition in the field of teaching can be close to those experienced in the art world, even though teachers' careers are far more institutionalized and predictable than those of artists.

The common thread between the artists studied in this dossier is the fact that they are neither rich (relative to the professional market in which they work) nor famous. They are neither "stars" nor "great" artists who are well known and celebrated. This is a situation experienced by most artists, and yet it is seldom studied. This sociology of the banal, which deals with artistic work in its most mundane aspects, has, for a long time, had only a few proponents. Examples include works by Cynthia White and Harrison C. White, who can be considered precursors; or Raymonde Moulin on painters' careers and the art market (but also, for Moulin, the colour print market) (White \& White 1965; Moulin 1967). Around the same period, Howard Becker's research into dance musicians also constitutes an original reference. For this reason, we invited him to share his reflections on the notion of ordinary artists in an interview published in this dossier. 
Howard Becker sur les musiciens de danse constitue aussi une référence originelle. C'est pour cette raison que nous l'avons invité à livrer ses réflexions au cours d'un entretien autour de la notion d'artistes ordinaires.

Il s'agit, dans ce dossier thématique, d'articuler le travail théorique essentiel de Becker autour de cette notion, avec les apports de la sociologie dite critique. En abordant différemment les hiérarchies entre artistes, ces deux approches permettent de penser de manière complémentaire le cas des artistes qui ne sont pas les plus haut placés. Le concept de « champ » permet de montrer les rapports de pouvoir, de concurrence et de domination entre les artistes occupant des positions dominantes et dominées, c'est-àdire entre ceux dont l'intérêt réside dans la conservation des hiérarchies et ceux qui cherchent à les subvertir. L'idée de « monde de l'art » chez Becker permet d'envisager ces hiérarchies comme des degrés d'intégration des artistes à des réseaux de coopération impliquant toutes les personnes qui produisent collectivement une œuvre et contribuent à la construction de sa valeur, que ces personnes participent directement ou non à la compétition artistique. La combinaison de ces deux approches, structurale et organisationnelle, permet au chercheur qui étudie des artistes ordinaires de s'interroger sur deux dimensions différentes d'un même problème : comment parvenir à exister comme artiste quand on n'occupe pas une position stable et visible, quand on n'est ni un « membre à part entière » du champ (Bourdieu 1998 : 370) ni un «professionnel intégré » au monde de l'art (Becker 1988) ? Ce problème se décline ainsi en deux questions complémentaires : 1. À quels principes de légitimité
The aim of this dossier is to link Becker's essential theoretical work on this notion to the theoretical contributions of "critical" sociology. Since these two approaches consider the hierarchies that exist between artists differently, they offer two complementary insights into the situation of lesserknown artists. The concept of "field" is used to emphasize the relations of power, domination, and competition between artists in dominant and in subordinate positions, that is to say, between those whose interests lie mostly in preserving hierarchies, and those who seek to subvert them. Becker's concept of "art worlds" can be applied to consider hierarchies as the various degrees in which artists are part of cooperative networks involving all those who collectively produce an artwork and who thus contribute to the construction of its value, whether these individuals directly participate in artistic competition or not. Combining these two approaches-one structural and one organizational-allows researchers who study ordinary artists to investigate two different dimensions of a singular problem: how does one manage to exist as an artist when one is not in a stable, visible position, nor a "fully fledged members of the field" (Bourdieu 1995: 226), nor an "integrated professional" in an art world (Becker 1982)? Let us rephrase this problem with two questions: 1. In which principles of legitimacy, in competition with established principles, should we believe? ; 2 . How does artistic activity exist in this case in concrete terms; that is to say, who are the 
concurrents des principes établis faut-il croire ? ; 2 . Comment existe concrètement l'activité artistique dans ce cas, avec quels acteurs est-elle menée et dans quels circuits est-elle diffusée ? La complémentarité de ces deux approches réside tout d'abord dans l'imbrication de leurs échelles d'analyse. Là où la perspective bourdieusienne donne des outils pour penser les manières dont des artistes ordinaires prennent position au sein du champ (i. e. quelles sont leurs références et leurs ambitions, et quelles sont au contraire les manières de faire de l'art qu'ils mettent à distance ?), la perspective beckerienne permet davantage de comprendre comment les artistes ordinaires mènent leur activité à l'intérieur du monde de l'art où ils ont fini par trouver leur place ${ }^{5}$. En retour, on peut considérer que la possibilité pour des artistes ordinaires d'accéder à des réseaux de coopérations qui font exister leurs œuvres constitue un support de leurs prises de position.

Au-delà de ces complémentarités, on peut souligner un point commun essentiel à ces deux approches. Sous la plume de Becker comme sous celle de Bourdieu, se déploie un constructivisme radical et s'engage une même prise de distance avec le mythe romantique de l'artiste en régimes « vocationnel » et « de singularité » (Heinich 1993) pour considérer l'art comme un travail. C'est précisément l'équation Art = Travail que propose Becker depuis Les Mondes de l'art (1988) jusqu'à ses plus récentes publications (Becker 2013). Quant à l'analyse bourdieusienne des champs artistiques,

5 Becker considère en effet que les artistes qui ne sont pas « intégrés " aux mondes de l'art existants peuvent être à l'origine de nouveaux mondes de l'art dotés de conventions et de réseaux de collaboration propres. participants, and through which circuits is it developed? The complementarity of these two approaches resides first in the imbrication of their scales of analysis. While the Bourdieusian perspective provides tools for analysis of how ordinary artists are positioned in the field (i.e., what their references and ambitions are and, conversely, from which ways of making art are they distancing themselves?), the Beckerian perspective allows us to understand how ordinary artists carry out their work within the art world in which they have ultimately found their place ${ }^{5}$. In return, we can consider that the possibility that ordinary artists have of accessing cooperative networks which allow their art to exist constitutes support for the attitude they take.

There is one further essential common aspect of these two approaches. In their writing, Becker and Bourdieu both deploy a radical constructivism and engage in the same distancing from the romantic myth of the life of an artist as "vocational6" and "unique" (Heinich 1993), to consider art instead as a form of work. It is precisely the Art $=$ Work equation that Becker proposes in works from Art Worlds (1982) up to his most recent publications (Becker 2013). Regarding Bourdieu's analysis of

5 According to Becker, artists who are not "integrated" into existing art worlds, can form new art worlds with conventions and cooperative networks of their own.

6 A general note on quotations in this journal: we have translated all nonEnglish language quotations for which we did not have access to a published translation. 
elle révèle bien l'écart qui existe entre la croyance dans ces espaces de « magie sociale » et de « dénégation du monde social » (Bourdieu 1977 ; 1994), et le travail incessant des artistes pour se faire reconnaître et pour trouver leur place, au prix souvent d'une série de renoncements et d'ajustements. On considère donc l'art comme un travail, mais un travail un peu particulier, engageant une «dramaturgie sociale » (Menger 2013) ou une " comédie humaine » (Linhart 2015) particulièrement intense, compte tenu du fait qu'il s'agit d'espaces de production de biens symboliques où l'on investit sa vie dans son travail, où l'on s'engage dans un rapport vocationnel et un style de vie marqués par une croyance dans le jeu social et artistique (« le musicien se considère comme possédant un don mystérieux qui le met à part des autres personnes ", Becker 1985 : 109). Pour autant, cela signifiet-il que l'on a toujours affaire à un travail de type vocationnel ou scolastique, dont l'exercice même constitue la première rétribution du travailleur? Assurément non. II existe de fait de nombreuses situations professionnelles artistiques qui contreviennent à cet idéal de « l'art pour l'art », des situations où des éléments $d u$ « style de vie artiste »-comme le refus des conventions sociales et de la « routine » (Bourdieu 1979) - sont en permanence articulés avec une vie finalement ordinaire.

L'objectif de ce dossier est de donner à voir ces carrières et situations banales, en développant une sociologie du travail artistique attentive aux structures sociales au sein desquelles il s'accomplit. Comment travaillent les artistes « ordinaires »? Quelles sont leurs activités ? Dans quelle mesure arrivent-ils à vivre de leur activité artistique ? Quels savoirs et savoir- artistic fields, it reveals the gap that exists between the belief in these spaces of "social magic" and "denial of the social world" (Bourdieu 1980; 1998), and the artists' incessant effort to become recognized and find their place, often at the cost of a series of renunciations and adjustments. Art can therefore be considered as a form of work, but a particular one which involves a "social dramaturgy" (Menger 2013) or an especially tense "human comedy" (Linhardt 2015) since it takes place in the spaces where symbolic goods are produced: where one dedicates one's life to one's work, and becomes engaged in a vocational relationship and a lifestyle marked by a belief in the social and artistic game. Hence, is artistic work always a vocational or scholastic kind of work, where its very exercise is the worker's first retribution? Certainly not. There are numerous professional artistic situations that go against the "art for art's sake" ideal-situations in which elements of the "artistic lifestyle"-such as the rejection of social conventions and "routines" (Bourdieu 1984)-are forever linked to a life that is ultimately ordinary.

This dossier aims at making those banal situations and careers visible, by developing a sociology of artistic work, attentive to the social structures within which it takes place. How do "ordinary" artists work? What are their activities? To what extent do they manage to live off their artistic activity? What knowledge and expertise do they employ? Where do 
faire mettent-ils en œuvre ? Dans quels lieux travaillentils ? À quelles formes de reconnaissance accèdent-ils ? Dans quels réseaux s'inscrivent-ils ? Comment construisent-ils (ou pas) leur singularité ? Dans quelle mesure ont-ils l'impression de faire de l'art, d'être artiste, etc. ? À ces questions, les contributions au dossier apportent des éléments de réponse en traitant, on l'a dit, de différents métiers artistiques. Toutefois, on peut déjà repérer plusieurs traits communs aux artistes ordinaires étudiés. Banalité " déviante », hétéronomie de l'activité, instabilité des carrières, reconnaissance partielle, et ambivalence entre réalités objective et subjective du travail semblent unanimement partagées par les artistes ordinaires.

\section{Banalité et déviance : le paradoxe des univers artistiques}

Les « artistes ordinaires » peuvent avant tout être définis par la banalité de leur condition. Loin de constituer un jugement dépréciatif sur leur production (on sait combien le terme disqualifie tout bien symbolique), l'emploi du qualificatif « ordinaire » désigne leur position dans l'espace professionnel. Ces artistes sont ordinaires, leur situation est banale, parce qu'elle est majoritaire dans les mondes artistiques. Ces univers très inégalitaires sont fréquemment représentés sous la forme d'une pyramide dont la base et les degrés inférieurs sont par définition beaucoup plus peuplés que le sommet. Les artistes ordinaires sont donc, et de loin, les plus nombreux. On pourrait multiplier les exemples, mais pour n'en mentionner qu'un seul : sur un échantillon donné d'écrivains dont la reconnaissance serait mesurée à celle de leurs éditeurs, on peut estimer que seuls $20 \%$ ont publié they work? What forms of recognition do they have access to? What networks are they a part of? How do they construct their uniqueness (or not)? To what extent do they feel they are making art, being artists, etc. ? Each contribution in this dossier brings a specific answer to these questions by dealing with different artistic professions. Yet, several common features can already be found among the various ordinary artists which are studied here. A "deviant" banality, the heteronomy of their activity, career instability, partial recognition, and the ambivalence between the objective and subjective realities of work seem to be shared by all ordinary artists.

\section{Banality and deviance: the paradox of art worlds}

Above all, "ordinary artists" can be defined by the banality of their condition. Far from constituting a depreciative judgment of their production (since this term traditionally tends to disqualify any symbolic good), the word "ordinary" as used in this expression, actually qualifies the artists' position in the professional sphere. These artists are indeed ordinary and their situation is banal because it is predominant in art worlds. These very inegalitarian spaces are often represented in the form of a pyramid whose base and lower rungs are far more populated than the top. Ordinary artists are therefore the most numerous, and by a long way. We could provide several examples but to mention only one: in a study comparing writers' fame with that of their publishers, in a given sample only $20 \%$ had published all their books with nationally recognized 
tous leurs livres chez des éditeurs à renommée nationale alors que près de $50 \%$ n'ont publié que chez des éditeurs « régionaux ${ }^{6}$ (Lahire $2006:$ 195-196).

Labanalité de leur situation contrevient pourtant à la perception la plus communément admise des univers artistiques (qui est aussi leur raison d'être) : les mondes de l'art seraient les lieux superlatifs de la révélation des « talents » exceptionnels, des singularités admirables et admirées. Les artistes ordinaires seraient ainsi en un certain sens les perdants dans ce que Pierre-Michel Menger appelle la « loterie aux talents 》 (Menger 2002). Toutefois, les espaces de production des biens symboliques, y compris les plus autonomes, ne fonctionnent pas de manière binaire, réduisant à la forclusion les non-consacrés, mais sont traversés par des formes et des degrés différents d'intégration et de réussite professionnelle. II n'y a pas d'un côté des gagnants, professionnels consacrés ayant touché le « gros lot », et de l'autre des perdants, exclus du marché du travail, mais il existe toute une gradation entre les états de vedette internationale des mondes de l'art et ceux de prestataire de service en animation culturelle ou commerciale. Les artistes ordinaires sont donc intégrés (plus ou moins bien) aux mondes de l'art et ils en constituent de fait les plus gros bataillons même s'ils ne sont pas les plus

visibles.

6 Si la recherche mentionnée ici porte sur des écrivains français recensés via un organisme de la Région Rhône-Alpes, leur lien avec cette région n'est pas forcément éditorial. Ils peuvent en effet vivre ou être nés dans cette région tout en publiant chez de grands éditeurs parisiens. publishers, whereas close to $50 \%$ had only published with a local publisher ${ }^{7}$ (Lahire 2006: 195-196).

The banality of the situation of ordinary artists runs counter to the common perception of art worlds (which is also their raison d'être): that they are the ultimate places for the revelation of exceptional "talent," and of admirable and admired originality. Ordinary artists would thus be in a certain sense the losers of what Pierre-Michel Menger calls the "talent lottery" (Menger 2002). However, the spaces of production of symbolic goods, even those that are the most independent, do not work in a binary fashion, banishing artists who have not achieved recognition; instead they bear the marks of different forms and degrees of integration and professional success. There are not winners on one side-the established professionals who have hit the "jackpot" - and losers on the other side, excluded from the job market; in fact, a gradation exists between the conditions of the international stars of the art world and those of service providers in commercial or cultural organizations. Ordinary artists are therefore (to a greater or lesser extent) integrated into art worlds, and account for the largest portion of its population even if they are not the most visible.

7 While the research mentioned here is about French writers surveyed by an organization in the Rhône-Alpes region, their link to this region is not necessarily editorial. They may live in or be from this region while publishing through major Parisian publishers. 
De manière apparemment paradoxale, l'« artiste ordinaire » est aussi un artiste hors norme. On peut en effet considérer que la norme dans la conception romantique de la figure de l'artiste qui prévaut depuis le $\mathrm{XIX} \mathrm{X}^{\mathrm{e}}$ siècle, est celle du créateur comme être d'exception, forcément en marge, singulier et irréductible aux prosaïsmes matériels du commun des mortels (Barthes 1957 ; Bourdieu 1979). Dès lors, la figure de l'artiste ordinaire relèverait d'un écart à la norme, tout en constituant la situation la plus courante. De fait, il existe un hiatus, y compris parmi les artistes, entre les représentations collectives de l'art et les pratiques réelles, comme l'a montré Séverine Sofio dans le cas des plasticien.ne.s au XIX ${ }^{\mathrm{e}}$ siècle (Sofio 2016). L'artiste ordinaire s'écarte donc de la norme qui veut qu'un artiste soit exceptionnel mais il est pourtant le cas majoritaire, cherchant à exister, à « sortir du lot », mais vivant et construisant sa carrière dans la condition banale d'un métier. C'est bien cet écart à la norme de l'exceptionnalité singulière comme moyen et expression de la réussite sociale qui fait apparaître le travail artistique ordinaire comme paradoxal. L'immense majorité des artistes peut alors apparaître comme un ensemble de « médiocres », susceptibles d'être stigmatisés et étiquetés comme imposteurs. En témoigne par exemple la rhétorique mobilisée depuis vingt ans par les détracteurs radicaux du régime d'assurance chômage spécifique aux salariés intermittents du spectacle en France : les « intermittents » ne seraient que des « feignants » (parce que ne travaillant pas assez pour échapper au chômage) sans « talent » (parce qu'ayant besoin des subsides de l'État pour vivre, l'exercice de leur art n'y suffisant pas).
In what appears to be a paradox, the "ordinary artist" is also outside the norm. The norm in the characterisation of the artist is the romantic conception, common since the nineteenth century, of the artist as an exceptional creator and as a solitary individual, both unique and irreducible to the material, daily concerns of common mortals (Barthes 1972; Bourdieu 1984). From that perspective, the figure of the ordinary artist would constitute a deviation from the norm while representing the most common situation. In fact, there is a rift, even among artists, between collective representations of art and real practices, as Séverine Sofio showed in the case of nineteenth-century male and female painters and sculptors (Sofio 2016). Ordinary artists therefore separate themselves from the norm which requires an artist to be exceptional while they constitute the majority in art worlds, seeking to exist, to "stand out from the crowd," but experiencing and building their career within the banal conditions of an occupation. It is precisely this deviation from the norm of singular exceptionality as a means of expression of social success, which makes ordinary artistic work appear paradoxical. The vast majority can thus appear to be a set of "mediocre" artists, vulnerable to stigmatization and labelled as imposters. As can be seen in the rhetoric employed in the past twenty years by radical opponents of the French unemployment insurance system specifically for intermittents (contract workers) in the performing arts: claimants are labelled "frauds" (since they do not work enough to escape unemployment) and "talentless" (since they need state subsidies to live because their revenue from artistic activities is not enough). 


\section{Des activités hétéronomes}

Cette situation apparemment paradoxale conduit les artistes ordinaires à mener leur activité souvent loin d'un idéal d'autonomie créatrice et ne leur permet que rarement de s'ajuster sur le « style de vie artiste » (Bourdieu 1979), dans la mesure où il leur est impossible d'être tout le temps et

partout reconnus comme « artistes ».

\section{Le rapport au public et les enjeux commerciaux}

Les artistes ordinaires sont des artistes qui « font le job », le « métier », et dont la création est loin d'être autonome, dégagée des contraintes commerciales et du souci d'adaptation au public (Bourdieu 1971). Ainsi Becker a-t-il étudié « des personnes qui jouent de la musique populaire pour gagner de l'argent » (Becker 1985 : 105), obligées de diversifier à la fois leur répertoire pour s'adapter aux goûts du public, et leurs lieux de diffusion, eux aussi «populaires » (bars, fêtes, etc.). Perrenoud a enquêté cinquante ans après Becker dans une position similaire d'observateur participant (tous deux ont fait de l'activité musicale à la fois leur métier et leur terrain d'enquête) et a retrouvé le même type de groupe professionnel, tiraillé entre désir d'autonomie et nécessité commerciale. Si cette tension semble intrinsèquement liée à la condition d'artiste quel que soit son degré de reconnaissance, elle est particulièrement prononcée chez les artistes ordinaires. Ces derniers semblent « faire le métier » selon un type particulier de rapport au travail et à l'emploi. Ils sont des indépendants, prestataires de services, des artisans de l'entertainment et de l'animation (musiciens, comédiens, danseurs) ou du graphisme et de l'illustration (plasticiens,

\section{Heteronomous activities}

This seemingly paradoxical situation is also what causes ordinary artists to carry out their work far removed from an ideal creative autonomy and only sometimes allows them to adopt an "artistic lifestyle" (Bourdieu 1984), as, most of the time and in most places, they cannot be recognized as "artists."

\section{The relationship to the public and commercial concerns}

For this reason, ordinary artists "do the job" - the "trade"and their creation is far from autonomous, detached from commercial constraints and the concern of adapting (their art, their lifestyle, etc.) to the expectations of an audience (Bourdieu 1985). Thus, Becker (1963) studied musicians, who needed to diversify not only their repertoire according to audience tastes, but also their performance venues so as to include more "popular" ones (bars, parties, etc.). Perrenoud investigated this same issue fifty years after Becker, from a similar position of participant observer (both made music their line of work as well as their field of research) and found the same type of occupational group, torn between a desire for autonomy and commercial necessity. While this tension seems to be intrinsically linked to the artist's condition whatever his/ her level of fame, it is particularly strong for ordinary artists. Indeed, the latter seem to "do the job" while having a particular attitude to work and employment. They are independent service providers, craftsmen of entertainment and animation (musicians, comedians, dancers), of graphic design and illustration (plastic artists, and factory draughtsmen of the eighteenth century). In certain cases, their activities take 
dessinateurs de manufacture du XVIII siècle). Dans certains cas, les activités de ces artistes ordinaires se déroulent à la marge ou en dehors des mondes de l'art (le comédien qui fait le père Noël dans une galerie marchande, le musicien qui joue des jingles pour la montée au micro de chaque orateur dans une cérémonie, etc.), et les artistes deviennent alors eux-mêmes un personnel de renfort dans le dispositif en place : I'hétéronomie est totale, l'artiste est un auxiliaire.

Dans le cas des musiciens ordinaires, il s'agit bien, comme Becker l'a déjà dit, de « personnes qui sont prêtes à jouer tout ce qu'on leur demande dans les limites de leurs capacités. [...] Les stars du jazz, ce sont ceux qui ne sont plus obligés de faire tout cela et qui peuvent vivre des concerts et de la vente de leurs disques. Cela doit représenter deux ou trois cents personnes tout au plus » (Azaïs, Bachir-Loopuyt, Saint Germier 2010). Le métier de musicien est peut-être le plus évidemment concerné par cette dimension tant les usages sociaux de la musique live sont diversifiés, offrant notamment toute une gamme d'emplois d'animation anonyme (voir l'ethnographie de prestations d'animation pour le Rotary Club, la remise des diplômes d'une école de commerce ou encore l'assemblée générale des fédérations de pêche dans Perrenoud 2006 et 2007). Dans les autres disciplines artistiques, il existe aussi des modalités particulièrement déclassées de l'inscription sociale de l'activité et des carrières dans le rapport au public et au commerce. Par exemple, dans le domaine de la littérature, de très nombreuses possibilités d'interventions publiques existent, dans des lieux plus ou moins liés au livre ou au " savoir » (bibliothèques, librairies, salons du livre, salles de classe, mais aussi offices du place on the fringes of, or outside art worlds (like the actor who plays Santa Claus in a shopping mall, the musician who plays jingles for each speaker who goes up to the microphone during a ceremony, etc.). Artists then become backup personnel in the system that is in place: the heteronomy is complete; the artist is an auxiliary.

As for ordinary musicians, they are, as Becker has already said, "people who are ready to play anything they are asked to play within the limits of their abilities. [...] Jazz stars are the ones who are no longer obligated to do all of that, who can live off their concerts and their record sales. They represent two or three hundred people at the most" (Azaïs, Bachir-Loopuyt, Saint Germier 2010). Musicians' jobs are perhaps the most clearly concerned with this dimension since the social functions of live music are so varied, offering, in particular, a wide range of anonymous gigs and functions (see the ethnography of performance service providers for the Rotary Club, graduation ceremonies at a business school, and even the general assembly of French fishing federations in Perrenoud 2006 and 2007). Similarly, in other artistic disciplines, there are also relegated modes of making art and a career, because of a particularly downgraded relationship to the audience and to commerce. For example, in the literary world, there are many opportunities to work with the public, in spaces that are connected, to varying degrees, to books or "knowledge" (libraries, bookstores, book fairs, classrooms, but also tourism offices, fairs dedicated to local cuisine, markets, etc.), and under forms that are also connected, to varying 
tourisme, foires dédiées à la gastronomie locale, marchés, etc.) et sous des formes plus ou moins éloignées d'une visée commerciale explicite (de la lecture publique à la vente de livres sur un stand), ces gradations dans la forme des interventions recoupant le caractère plus ou moins légitime de ces dernières (Bois 2014)

\section{La mise en jeu de compétences sociales « ordinaires 》}

Être un artiste ordinaire, c'est aussi devoir composer avec les rapports sociaux « ordinaires ». Quand on n'est ni riche ni célèbre, quand on travaille en prestataire de service ou comme employé, on ne peut se comporter comme un artiste exceptionnel et fantasque (voir à ce propos l'entretien avec Becker en fin de dossier).

De fait, quand on ne peut se prévaloir d'une reconnaissance instituant la figure de l'artiste inspiré, singulier, et donc forcément un peu « différent », on doit se conformer à des principes communs minima de "savoir être » et de « professionnalisme ». Pour les musiciens ordinaires par exemple, mener une carrière locale pendant des décennies suppose la mise en œuvre d'une série de compétences très différentes de celles que l'on peut s'attendre à trouver chez des « artistes » et très éloignées du « style de vie artiste », des compétences finalement très ordinaires. En effet, le métier des musiciens ordinaires se développe souvent en l'absence d'intermédiaires (Jeanpierre \& Roueff 2014 ; Lizé, Naudier, Sofio 2014$)^{7}$ si bien que les artistes doivent eux-mêmes jouer

7 Les intermédiaires du travail artistique ayant un rôle important dans la construction de la valeur d'un artiste, on comprend d'autant mieux qu'ils soient souvent absents dans le cas des artistes ordinaires. degrees, to explicitly commercial purposes (from public readings to the sale of books on a stand). These gradations in the form of interventions corroborate to varying degrees the latter's legitimacy (Bois 2014).

\section{The implementation of "ordinary" social competences}

To be an ordinary artist means having to deal with "ordinary" social relations. Being neither rich nor famous, working as a service provider or employee means not being able to behave like an exceptional, fanciful artist (see interview with Howard Becker at the end of the dossier).

In fact, when one cannot lay claim to the level of recognition that is due to an inspired, unique artist, who therefore necessarily a little "different," one must conform to the common principles of "soft skills" and "professionalism." For ordinary musicians, for example, having a local career over the course of decades requires the use of a set of very different skills to those expected of "artists" and an "artistic lifestyle;" skills that can indeed be regarded as very ordinary. For instance, ordinary musicians generally do not employ intermediaries (Jeanpierre \& Roueff 2014; Lizé, Naudier, Sofio 2014) ${ }^{8}$, meaning they have to be their own agents (to sell or negotiate), technicians (to set up the sound, regulate

8 Since intermediaries in artistic fields often play an important role in building the value of an artist, it is much easier to understand why they are not often present in ordinary artists' careers. 
ces rôles d'agent (vendre, négocier), de technicien (monter la sono, régler l'équilibre sonore - la balance, transporter les instruments et les amplis), ou de chauffeur. On a aussi pu montrer combien la rareté des intermédiaires rend difficile la posture de «pureté » artistique chez les écrivains peu reconnus, souvent contraints de se charger eux-mêmes de la diffusion et de la promotion de leurs livres à la place de l'éditeur, démarchant les librairies, fréquentant assidûment les salons du livre, et développant in fine des compétences, et parfois un goût, pour les rencontres directes avec le public que des écrivains plus reconnus peuvent se permettre de dénigrer (Bois 2013). Finalement, pour les artistes ordinaires, les modalités de la pérennisation d'une carrière locale passent souvent par la satisfaction du client, l'établissement d'une relation de confiance et d'une réputation par le boucheà-oreille, dans un registre très proche de celui qui préside habituellement au rapport au travail des artisans.

\section{Une carrière instable et une démultiplication nécessaire de l'activité professionnelle}

L'un des traits les plus significatifs et spécifiques des activités artistiques est leur caractère instable et imprévisible qui les situe à l'une des deux extrêmités du continuum de la précarité au travail, le pôle opposé étant occupé par des activités très réglementées notamment dans de grandes institutions comme l'armée ou la fonction publique (hôpital, éducation). Ce faible degré d'institutionnalisation des activités artistiques a conduit nombre de chercheurs et de chercheuses à questionner le terme de «professionnel » pour les désigner (par exemple Freidson 1986), voire à récuser la pertinence the sound balance, and transport instruments and amplifiers), and even drivers. It has also been shown that the rarity of intermediaries makes the posture of artistic "purity" very difficult to maintain for lesser-known writers, insofar as they are often in charge of their own books' distribution and promotion in the absence of a publisher to do this; they are also in charge of approaching bookstores, and frequently go to book fairs; as a consequence, they develop skills in, and sometimes even a taste for, dealing directly with the public-something that more famous writers tend to denigrate (Bois 2013). Finally, for ordinary artists, establishing a local career often depends on client satisfaction, the establishment of trust, and a wordof-mouth reputation very similar to that which usually governs the work of artisans.

\section{An unstable career and a necessary diversification of professional activity}

One of the most significant and specific features of artistic activities is their unstable and unpredictable nature, which places them at one end of the employment instability continuum, the opposite end being occupied by professions that are highly regulated, especially in large institutions like the army or the public sector (hospitals, education, etc.). This low degree of institutionalization for several artistic activities has led many researchers to question the use of the word "professional" for their designation (for example, Freidson 1986), and even to recuse the pertinence of this vocabulary 
de ce vocabulaire pour les disciplines artistiques étudiées (Lahire 2006). II est vrai qu'être artiste c'est dépendre du désir des autres, ce qui signifie très souvent connaître des périodes répétées d'alternance entre travail rémunéré et/ou déclaré et travail non-rémunéré et/ou non déclaré, et donc une forte variabilité des revenus. Pour certaines professions du spectacle, s'ajoute une précarité particulière liée au fait que le corps est l'outil principal de travail et les difficultés rencontrées par les comédiens vieillissants (Cardon 2014 ; Katz 2015) ou par les danseuses au moment de la maternité (Sorignet 2004) rappellent forcément ce que l'on sait des carrières sportives, elles aussi très inégalitaires, marquées par le risque permanent d'être trahi par son corps et par ailleurs largement soumises à l'idéologie du « talent » (Schotté 2012). Les carrières artistiques sont donc loin d'être linéaires, excepté pour les artistes très reconnus, relativement protégés des aléas du métier (par exemple dans le milieu littéraire, grâce à l'obtention d'un très grand prix, Lahire 2006). Ainsi, les « sorties de carrière " sont des situations ordinaires pour les artistes, comme le montrent notamment l'article de Serge Katz consacré aux comédiens qui ont connu des trajectoires d'exclusion (définitive ou temporaire) de l'indemnisation chômage et celui de Jérémy Sinigaglia qui, en analysant ce qu'il advient des artistes du spectacle vivant pour qui « la consécration ne vient pas ", met au jour diverses formes de reconversion professionnelle. Ces reconversions sont sans doute plus ou moins fréquentes selon le degré de professionnalisation des disciplines. Dans les métiers du spectacle, les possibilités plus grandes de vivre - même chichement - de l'activité artistique encouragent certainement les jeunes artistes à « tenter leurs chances », au moins dans for artistic disciplines (Lahire 2006). It is true that being an artist means depending on the desire of others, which often means experiencing continual periods of alternation between paid and/or legitimate jobs and unpaid and/or under-the-table work, the consequence being a high variability of revenue. For people working in the performing arts - who are dependent on their bodies for work-employment instability is even more significant. The difficulties faced by ageing performers (Cardon 2014; Katz 2015) or by dancers who become mothers (Sorignet 2004) recall what we know of athletes' careers, which are also very inegalitarian, marked by the permanent risk of being betrayed by one's body and, moreover, largely subjected to the ideology of "talent" (Schotté 2012). Artistic careers are therefore far from being linear, except for wellknown artists, who are relatively sheltered from the hazards of the business (for example, in the literary world, those who have won prestigious awards, Lahire 2006). Thus, "career exits" are a common occurrence for artists, as shown in Serge Katz's article on actors who have been barred (either temporarily or definitively) from receiving unemployment benefits, and in that of Jérémy Sinigaglia, which, by analysing what happens to live performance artists for whom "consecration [...] never comes," shows diverse forms of professional reconversion. Such career changes undoubtedly depend on the degree of professionalization in the discipline. The greater opportunities to make a living-albeit a frugal one-from artistic work in the performing arts certainly encourages young artists to "try their luck," at least at first, by dedicating themselves entirely to this activity, even if it means changing course later. In the literary world, on the other hand, everything happens as if the question of reconversion did not even need to be asked. 
un premier temps, en se consacrant entièrement à cette activité, quitte à se reconvertir dans un second temps. Dans le domaine de la littérature au contraire, tout se passe comme si la question de la reconversion ne se posait pas. En effet, les espoirs de « vivre de sa plume » sont tellement minces que l'orientation vers un métier rémunérateur, à côté de l'écriture, est d'emblée une nécessité pour la plupart des écrivains, même les plus reconnus (Lahire 2006), ce qui évacue de fait la question de la reconversion. Chez les artistes intermittents du spectacle, on sait d'une manière générale que le turn-over est très important. On observait ainsi il y a plus de dix ans un renouvellement annuel de près de la moitié des intermittents indemnisés (Roigt \& Klein 2002).

Du fait de cette fluctuation des revenus artistiques, la situation des artistes qui diversifient leurs activités afin d'assurer leur survie économique est donc tout à fait « ordinaire » elle aussi (Lahire 2006 ; Bureau, Perrenoud, Shapiro 2009), qu'ils enseignent leur art, qu'ils occupent des emplois de «personnel de renfort » (Becker 1988) ou d'intermédiaires dans les mondes de l'art, ou encore qu'ils occupent des emplois extérieurs au domaine artistique. Cette situation est abordée par plusieurs articles du dossier qui montrent qu'elle peut être vécue de manière très variée, et pas forcément sur le mode de la contrainte. Ainsi, la distinction entre pluriactivité (exercer plusieurs métiers dans un même monde de l'art) et multiactivité (exercer différents métiers dans des espaces sociaux différents), telle qu'elle a été proposée par Janine Rannou et lonela Roharik (2006), est-elle fondamentale pour envisager des situations où les différentes activités professionnelles peuvent plus aisément
The chances of "living by the pen" are so slim that seeking a paid position of some kind in addition to writing is a necessity from the start for most writers, even the most well known (Lahire 2006). For intermittent performing artists, turnover is very high. We thus observe that, for more than ten years, nearly $50 \%$ of intermittent performers have renewed their unemployment benefits annually (Roigt \& Klein 2002).

Owing to this fluctuation of artistic revenues, the situation for artists who diversify their activities to ensure their economic survival is also entirely "ordinary" (Lahire 2006; Bureau, Perrenoud, Shapiro 2009), whether they teach their art, occupy "support personnel" positions (Becker 1982), act as intermediaries in art worlds, or still hold positions outside of the arts altogether. This situation is addressed by several articles in the dossier which show that it can be experienced in a wide variety of ways, and not always as a form of constriction. From this perspective, the distinction between pluriactivity (having several jobs in the same artistic field) and multiactivity (having different jobs in different social spaces), such as proposed by Janine Rannou and Ionela Roharik (2006), is fundamental for envisioning situations where different professional activities can more easily support one another (writer and translator; musician and soundman; actor and director) and others where, conversely, they are objectively quite distant and more 
se nourrir mutuellement (écrivain et traducteur ; musicien et sonorisateur ; comédien et metteur en scène) et d'autres où, à l'inverse, elles sont objectivement très éloignées et davantage susceptibles d'être vécues comme concurrentes (écrivain et garagiste ; musicien et ramoneur ; comédien et ingénieur ${ }^{8}$ ). Comme l'explique Jérémy Sinigaglia dans son article, cette diversification est souvent le résultat de l'ajustement des aspirations des artistes ordinaires qui s'investissent par exemple dans « l'utilité sociale de l'art » (animation et médiation culturelles). Le phénomène de réduction des aspirations est aussi travaillé dans cet article à travers l'analyse des formes « modestes » de reconnaissance des artistes ordinaires qui constitue un autre axe important de ce dossier

\section{Des espaces et des formes mineurs de reconnaissance}

La réflexion proposée dans ce dossier s'inscrit également dans la lignée des travaux dirigés par Raymonde Moulin sur la population des artistes plasticiens en France (Moulin et al. 1985). Ces travaux, en effet, proposent non pas une définition

8 On peut aussi repérer des cas de multiactivité « heureuse » où IDactivité qui rapporte l'essentiel des revenus, bien que totalement déconnectée des mondes de l'art, est une source d'inspiration ou permet justement de conserver une forme de pureté artistique. C'est le cas pour certains écrivains (cf. certains portraits d'écrivains excerçant " des métiers hors culture », Lahire 2006) ou pour certains musiciens notamment dans le domaine des musiques improvisées radicales qui, grâce à un daytime job loin des mondes de l'art, peuvent tenir un rapport à l'activité artistique « purement vocationnel » parce que désintéressé (Perrenoud 2009 : 91-93), mais cette posture est difficilement compatible avec une représentation de soi comme «professionnel ». likely to be viewed as incompatible (writer and mechanic; musician and chimney sweep; actor and engineer ${ }^{9}$ ). As Jérémy Sinigaglia explains in his article, this diversification is often the result of an adjustment of the aspirations of ordinary artists who invest themselves, for example, in the "social utility of art" (cultural and life mediation). The phenomenon of reducing these aspirations is also addressed in this article through an analysis of the "modest" forms of recognition of ordinary artists who constitute another important link in this dossier.

\section{Spaces and minor forms of recognition}

The reflection proposed in this dossier chimes with the line of research carried out by Raymonde Moulin on artists in France (Moulin et al. 1985). This work, indeed, did not propose a restricted definition of artists limited to the best known, but a broad definition of the population, envisioning degrees within a space perceived as a continuum or scale. By collecting as

9 One can also find cases of "happy" multiactivity when the work that brings in the most revenue, while being totally disconnected from the art world, is a source of inspiration or allows the artist to maintain a level of artistic purity. This is the case for some writers (cf. certain profiles of writers doing "jobs outside of the cultural sector," Lahire 2006) or musicians, especially those in the domain of radical improvised music who, thanks to their day job far from the art world, can maintain a "purely vocational" relationship to their artistic work (Perrenoud 2009: 91-93), but this stance is not entirely compatible with a "professional" self-image. 
restreinte des artistes limitée aux plus reconnus d'entre eux, mais une définition large de cette population, envisageant des degrés à l'intérieur d'un espace pensé comme un continnum ou une échelle. En collectant un maximum de listes dans lesquelles sont cités des noms d'artistes (programmes d'expositions individuelles ou collectives, listes d'associations, etc.), les auteurs recensent ainsi « les artistes plasticiens de toutes les écoles et de toutes les tendances, même ceux qui ne sont pas enregistrés officiellement comme tels ou ceux dont la renommée est faible » (Singly (de) 1986 : 532), avant de les différencier en fonction de ces degrés de renommée. Ce faisant, ils affirment la nécessité de prendre en compte tous les espaces de reconnaissance - plus ou moins prestigieux - des artistes et l'absence de rupture radicale entre ces espaces (comme l'avait déjà fait Raymonde Moulin auparavant en soulignant les circulations possibles entre le marché des chromos et le marché des chefs d'œuvre, Moulin 1967). Les travaux de Géraldine Bois sur les écrivains et ceux de Marc Perrenoud sur les musiciens permettent d'illustrer la pertinence de cette acception relative de la notion de reconnaissance tout comme, par exemple, l'étude des chefs d'harmonies d'Alsace menée par Vincent Dubois, Jean-Matthieu Méon et Emmanuel Pierru (Dubois et al. 2009). Ces artistes ordinaires sont peu reconnus dans le champ « global » (respectivement, le milieu de l'édition française, l'espace national et international des « musiques actuelles » et le champ de la musique d'orchestre), mais ils peuvent jouir d'une reconnaissance importante dans le champ local, reconnaissance qu'il faut prendre au sérieux. many lists citing the names of artists as possible (individual or collective exhibition programmes, association lists, etc.), the authors thereby gathered "artists from all the schools and with different styles, even those who are not officially registered as such and those who are not well-known" (Singly (de), 1986: 532), before differentiating them according to how well known they were. In doing this, they affirmed the necessity of considering all spaces of recognition (of varying levels of prestige) for artists, and the lack of a radical rupture between these spaces (as Raymonde Moulin had done previously by underlining the possible overlaps between the colour print market and the market for masterpieces, Moulin 1967). The work of Géraldine Bois on writers and those of Marc Perrenoud on musicians show the pertinence of this relative acceptance of the notion of recognition, as does, for example, the study of wind band directors in Alsace, carried out by Vincent Dubois, Jean-Matthieu Méon, and Emmanuel Pierru (Dubois et al. 2009). These ordinary artists are not well known on a "global" scale (respectively the in French publishing milieu, the national and international space of popular music, and the field of orchestral music), but they can enjoy wide recognition locally, which ought to be taken seriously. 


\section{L'importance des réseaux locaux pour la carrière}

Nombre de musiciens ordinaires ont ainsi développé une carrière locale, acquérant une certaine célébrité dans leur ville de province, apparaissant toute l'année dans les cafésconcerts et les festivals de la région, faisant autorité sur le milieu local, détenant le pouvoir d'adouber les plus jeunes pour les aider à jouer dans tel bar musical, etc. Les artistes ordinaires existent non pas en dehors de toute reconnaissance, mais bien à un niveau local de reconnaissance, devenant parfois de « gros poissons dans un petit étang » au lieu d'être perdus dans le " grand bain » de la compétition au plus haut niveau de légitimité. Se construisent ainsi des carrières locales, des légitimités toutes relatives et des modes mineurs de reconnaissance à l'intérieur de réseaux locaux. La régularité des partenariats avec les employeurs locaux, la reproduction de la prestation, donc son manque de singularité, inscrivent l'activité dans un registre « continu ». C'est, par exemple, le cas des musiciens qui vont jouer tous les mardis soir dans le même bar-club avec les mêmes partenaires et plus ou moins le même répertoire ; c'est, de même, le cas des dessinateurs qui vont illustrer toutes les couvertures d'une série d'ouvrages pour le même éditeur, en suivant une charte graphique imposée. Ces modalités du travail artistique sont à l'opposé du régime de singularité qui caractérise les mondes de l'art les plus légitimes et où seule vaut l'expression exceptionnelle du talent dans le registre discontinu, valorisant par exemple la rareté du concert unique dans une ville ou de la production d'une œuvre graphique originale et authentique.

\section{The importance of local networks for careers}

Many ordinary musicians have thus developed a local career, achieving a certain level of celebrity in their city, appearing all year in musical bars and regional festivals, becoming authorities on the local scene, having the power to help younger musicians to play in one joint or another, etc. Ordinary artists do not exist outside of all recognition, but rather at a level of local recognition, therefore becoming "big fish in a small pond," instead of becoming lost in the seas of competition at the highest level of legitimacy. So local careers are built, relative legitimacies, and minor modes of recognition within local networks. The regularity of partnerships with local employers, recurring performances, thus the lack of uniqueness, defines the work as "continuous." This is the case, for example, for musicians who play every Tuesday night in the same bar or club with the same partners and the same repertoire: this is the same case for illustrators who work on each cover of a series of books for the same publisher, by following an imposed graphic chart. These modes of artistic work are in opposition to the regime of uniqueness that characterizes the most legitimate art worlds, where only the exceptional expression of talent matters, in a "discontinuous" way, valuing, for example, the rarity of the only concert in a city or of the production of an original and authentic graphic work. 


\section{Distinguer les conditions d'exercice de l'activité}

II faudrait ainsi typifier les dispositifs, les lieux et les modalités d'exercice du travail artistique et leur légitimité relative pour mesurer l'étendue du spectre de la reconnaissance. Par exemple, Marc Perrenoud a pu montrer comment l'inscription sociale de l'activité musicale et de la figure du musicien dépendent largement du type de « dispositif socioesthétique » dans lequel les artistes sont engagés (Perrenoud 2006 et 2007). Ainsi, un même musicien peut jouer dans une situation de concert, dans un lieu et un temps exclusivement dédiés à la musique, devant un public spécialement venu pour le spectacle, soutenu par des intermédiaires et du personnel de renfort (techniciens, administrateurs, etc.), ou bien jouer dans un bar ou sur une place de village en situation d'entertainement pour une "soirée ", une fête à laquelle la musique participe, pouvant avoir une place centrale mais pas exclusive, ou enfin officier dans le cadre d'une animation anonyme dans un lieu et pour un événement non musical (comme on l'a vu plus haut à propos des activités hétéronomes), sans être écouté ni encore moins applaudi. Dans ces différents dispositifs du travail musical en public, on passe d'une situation relativement légitime, conférant potentiellement une reconnaissance importante et instituant en tout cas le musicien comme créateur singulier (le concert), à une situation où, en bon artisan prestataire de service, on produit de la musique pour augmenter la plus-value symbolique associée à un événement (animation anonyme), en tenant un rôle social similaire à celui du traiteur

par exemple.

\section{Distinguishing working conditions}

It is therefore necessary to typify the settings, and the sites of artistic work, and the ways in which it is carried out, and their relative legitimacy, to measure the extent of recognition. For example, Marc Perrenoud has shown how the social role of music and of the musician depend a great deal on the type of "socioaesthetic setting" in which artists are involved (Perrenoud 2006; 2007). In this way, the same musician can play a concert, in a place and time exclusively dedicated to music, before an audience which has come specifically for that performance, supported by intermediaries and support staff (technicians, administrators, etc.), or play in a bar or a local entertainment space for a "night out," a party where music plays a role which, thought it may be central, is not exclusive, or, finally, officiate an anonymous performance, a labour in a place or for a non-musical event (such as we have seen previously regarding heteronomous activities), without being heard and even less applauded. In these different settings for public music work, we go from a situation of relative legitimacy, conferring potentially wide recognition and presenting the musician in any case as a unique creator (concert), to a situation where, as a good service provider, music is produced to increase the symbolic added value of an event (anonymous performance), by taking on a social role like that of a caterer, for example. 
On gagnerait probablement à chercher des équivalents dans les autres domaines artistiques et à montrer comment les lieux, les organisations, les structures dans lesquels s'exercent les activités des artistes ordinaires sont à chaque fois des éléments de classement, reclassement ou déclassement, dans le milieu professionnel concerné, mais aussi les ressorts d'une permanente redéfinition de l'identité d'artiste ou, pour le dire autrement, du vécu subjectif du travail artistique.

\section{Des tensions fréquentes entre situation objective et vécu subjectif de l'activité artistique}

Concernés par des formes mineures de reconnaissance et des activités souvent hétéronomes où l'on abandonne tout ou partie du pouvoir décisionnel sur le contenu de son travail, les artistes ordinaires vivent logiquement des situations fréquentes de décalage, voire de tension, entre ces conditions objectives d'exercice de leur art et leur illusio, au sens de " croyance fondamentale dans l'intérêt du jeu et la valeur des enjeux qui est inhérente à [l']appartenance [au champ] » (Bourdieu 2003 : 25). Les jeux artistiques étant régis par des valeurs d'exceptionnalité, de liberté et de gratuité, ces artistes ont particulièrement tendance à expérimenter une contradiction entre la nature supposée exceptionnelle de leur «identité d'artiste » et la banalité de leur condition, entre l'idéal de la liberté créatrice et les contraintes de leur production, entre l'idéal de « l'art pour l'art » et la réalité de l'instrumentalisation de leurs œuvres. On peut déjà identifier quelques manières de vivre ces tensions que les articles du dossier abordent en partie :
It would be worthwhile to search for equivalents in other artistic domains, to show how places, organizations, and structures within which the activities of ordinary artists take place are always elements of ranking, reclassification, downgrading, in the professional milieu in question, but also the springs of a permanent redefinition of the artistic identity or, to put it another way, of the subjective lived experience of artistic work.

\section{Frequent tensions between the objective situation and subjective lived experience of artistic work}

Concerned with minor forms of recognition and often heteronomous activities where one abandons all or some decision-making power over the content of one's work, ordinary artists often experience periods of divergence, even tension, between the objective conditions tied to their work and their illusio, in the sense of "fundamental belief in the value of the game and of the issues inherent to working in a given field" (Bourdieu 2000: 11). Since artistic activities are judged according to values of exceptionality, freedom, and gratuity, these artists are especially likely to experience a contradiction between the supposedly exceptional nature of their "artist identity" and the banality of their condition, between the ideal of creative freedom and the constraints of production, between the ideal of "art for art's sake" and the reality of the instrumentalization of their work. We can, from this point, identify some ways of living with these tensions that the articles in this dossier partially address: 
- la posture critique de l'artiste maudit. Certains artistes ordinaires peuvent se vivre comme des artistes « autonomes 》 justement parce qu'ils peinent à « en vivre ». Parmi les « musiciens de danse » étudiés par Becker (Becker 1985), les musiciens « de jazz » incarnent le pôle anti-commercial et adoptent une posture (que l'on retrouve depuis longtemps dans d'autres styles musicaux) d'opposition aux critères établis de réussite économique. Aujourd'hui, certains peuvent tenir une position marginale sur le marché en « refusant de se soumettre " à la demande du grand public comme les outsiders de Becker, mais aussi en " se tenant à l'écart " des instances de reconnaissance et de légitimité culturelle (subventions, prix et distinctions). Dans une réinterprétation de la bohème romantique héritée du $\mathrm{XIX}^{\mathrm{e}}$ siècle, ces artistes font de la pauvreté et de l'anonymat la marque d'une autonomie vertueuse ;

- l'accommodement modeste. La première reconnaissance, qui est en quelque sorte une reconnaissance a minima, réside probablement dans l'identification par autrui, le fait d'« être dit » écrivain, musicien, etc., permettant de « se sentir» écrivain, musicien, etc. (Heinich 1995). II s'agit ici d'« en être ", de faire partie du milieu, du groupe professionnel, en étant reconnu par ses pairs, comme le suggère par exemple Jacques Dubois qui pointe le rôle des cénacles (salons, revues, etc.) dans "l'émergence » d'un écrivain (Dubois 1978). Bien sûr cette forme de reconnaissance n'est que partielle, très relative, mais elle constitue une première étape indispensable et fondamentale pour les aspirants artistes, notamment quand leur accession à ces univers relève d'une
- the critical stance of the cursed artist. Some ordinary artists can live as "autonomous" artists precisely because they struggle to "live from their art." Among the "dance musicians" studied by Becker (1963), "jazz" musicians represent the anticommercial end of the spectrum and adopt a stance (which has now been present for years in other styles of music) against the established criteria for economic success. Today, some may hold a marginal position in the market by "refusing to submit" to the demand of the wider public, like Becker's outsiders but also by "keeping away" from instances of cultural legitimacy and recognition (subsidies, prizes, honours). In a reinterpretation of the nineteenth-century romantic bohemian lifestyle, these artists turn poverty and anonymity into a mark of virtuous autonomy;

- modest accommodation. The first recognition, which is, so to speak, a minimal recognition, is likely to come in the form of identification by others: the fact of "being called" a writer, musician, etc., which allows the individual to "feel like" a writer, musician, etc. (Heinich 1995). It is to do with "being of it," being a part of the scene, the professional group, being recognized by one's peers, as Jacques Dubois suggests when he points to the role of cenacles (salons, reviews, etc.) in "the emergence" of a writer (Dubois 1978). This form of recognition is, of course, only partial, and highly relative, but it nevertheless constitutes a first, indispensable, and fundamental step for aspiring artists, especially when their access to this sphere is also a social ascension. For some- 
ascension sociale. Pour certains - musiciens ordinaires issus des classes populaires par exemple (Perrenoud 2007) cette intégration au groupe professionnel constitue déjà une finalité. Être reconnu dans l'absolu, être consacré et considéré comme un « grand » dans le champ national ou international a pu être un rêve de débutant mais ne constitue que rarement une aspiration pour nombre d'artistes ordinaires engagés dans la carrière et ayant développé une rationalité qui s'accomode d'une position peu élevée sur la pyramide professionnelle, position qui se vit souvent sur le mode de l'artisanat modeste mais " authentique ». II en va de même avec les artistes en situation de pluriactivité qui peuvent s'accomoder d'un emploi alimentaire (illustrateur commercial par exemple) dans la mesure où il permet le maintien d'une pratique plus autonome mais peu rentable ;

- la persistance des ambitions. Si les manières de composer avec ces décalages peuvent, chez certains artistes ordinaires, donner lieu à de nouvelles formes de croyance ajustées à leur situation objective (lorsqu'ils finissent par se satisfaire de leur sort en adhérant à une définition plus large de l'artiste), les cas de persistance du désajustement (qui se manifeste par un sentiment durable de frustration et par des espoirs de succès jamais totalement abandonnés) ne doivent pas être minimisés. En effet, l'imprévisibilité des carrières artistiques laisse toujours la possibilité d'y croire malgré tout, en particulier dans les disciplines artistiques comme la littérature où la reconnaissance peut être acquise tardivement (Bois

2011) ordinary working-class musicians, for example (Perrenoud 2007) - this integration into the professional group already constitutes an end in and of itself. Being recognized in the absolute sense, being revered and considered "great" on the national or international stage can be an amateur's dream, but is rarely an aspiration for many ordinary artists who already have careers and have developed a rationality which aligns itself with a low-level position on the professional pyramid, a position which is often associated with modest, but "authentic" artisans. The same can be said of pluriactive artists who can adapt to supplementary employment (a commercial illustrator, for example) to the extent that it can allow the artist to create more autonomously but without making much money;

- the persistence of ambitions. While the means of accommodating these discrepancies can, for some ordinary artists, lead to new forms of belief adapted to their objective situation (when they end up satisfied with their place by adhering to a wider definition of being an artist), the persistence of discrepancies (which manifests itself in a durable sentiment of frustration and hope of success that is never completely abandoned) must not be minimized. In effect, the unpredictability of artistic careers always allows for the possibility of believing in them despite everything, especially in artistic disciplines such as literature, where recognition may come late in one's career (Bois 2011); 
- la requalification de l'activité. Dans leurs stratégies de diversification de l'activité, les artistes ordinaires sont couramment conduits à exercer des modalités diverses du « travail créatif », à la croisée des mondes de l'art et de la production industrielle ou commerciale. L'illustration (visuelle ou sonore) sur commande est un bon exemple de travail déclassé par rapport à la création autonome supposée être le seul mode d'activité légitime pour un artiste. Dans quelle mesure et à quelles conditions considère-t-on que l'on parvient malgré tout, dans ces cas-là, à « faire de l'art », à « être un artiste " ? Là encore, il est probable que les caractéristiques sociales (notamment la fraction de classe d'origine, le genre et le diplôme) ainsi que les dispositions qu'elles engendrent déterminent largement la possibilité de concevoir le travail créatif comme permettant de valoriser sa «fibre artistique », voire de se penser « artiste »;

- l'entrepreneuriat. Si certains artistes ordinaires ne se pensent pas comme des «perdants » et construisent des rapports au travail acceptables, c'est aussi, dans certains cas, en rompant avec l'illusio qui porte le champ et son idéal de " pureté » artistique. Développant de manière assumée une activité de service en entrepreneur efficace, l'artiste ordinaire devient alors un prospecteur de nouveaux marchés, "créant son emploi » comme le veut la vulgate libérale, en devenant par exemple un spécialiste de l'événementiel, vendant de l'animation musicale ou du spectacle de magie pour des soirées privées, ou bien un professionnel de l'intervention scolaire et du « jeune public » plaçant ses ateliers d'écriture ou de théâtre tout au long de l'année dans sa région. Fiabilité, adaptabilité, compétences techniques et administratives sont
- the requalification of activity. In their strategies for diversifying their work, ordinary artists are often led to perform in various modes of "creative work," at the intersection of the art world and industrial or commercial production. On-demand illustration (visual or sound) is a good example of work that is looked down upon in comparison with autonomous creation, which is the only legitimate kind of work for an artist. To what extent and under what conditions can someone manage, despite everything, in these cases, to "make art," to "be an artist"? It is likely that social characteristics (notably the class fraction of origin, gender, and qualifications) as well as the dispositions that they create largely determine the possibility of conceiving of creative work as something that allows for the valorisation of the "artistic character," or even of thinking of oneself as an "artist";

- entrepreneurship. While certain ordinary artists do not think of themselves as "losers," and build acceptable ways of carrying out their work, in some cases this also involves breaking with the illusio that comes with the territory and its idea of artistic "purity." By accepting the role of developing a service activity as an efficient entrepreneur, the ordinary artist then becomes a prospector of new markets, "creating his or her job" following the neo-liberal vulgate by becoming, for example, an event-driven specialist, selling musical performances or magic shows for private events, or even an education professional, providing writing or theatre workshops for schools throughout the year in their local region. Reliability, adaptability, and technical and administrative competencies are therefore the top qualities of these artists, some of whom 
alors les qualités premières de ces artistes dont certains se forment régulièrement à la gestion et à la communication. Par rapport aux deux premiers cas présentés en particulier, on a affaire ici à une figure locale de l'intégration professionnelle sur un mode entrepreneurial, en rupture avec la mythologie romantique de l'artiste pur et désintéressé mais en congruence avec la conception ultralibérale de la « création »

et de l'« innovation ».

Face à la banalité d'une condition d'artiste qui devrait « normalement » être exceptionnelle, le sentiment d'échec et de déclassement est donc loin d'être unanime et univoque. Ces différentes attitudes possibles (et l'on pourrait probablement en trouver d'autres) sont très largement liées aux inégalités dans la capacité toute sociale à percevoir la situation, notamment sa propre position dans le champ visà-vis des acteurs les plus légitimes. Par exemple, Bernard Lehmann a très bien montré les différences de perception du métier chez les musiciens salariés permanents des orchestres symphoniques parisiens (Lehmann 2002), y compris entre les membres d'un même pupitre, partageant les mêmes conditions de travail et d'emploi. On trouve ainsi différentes lectures de la même position objective (musicien du rang ${ }^{9}$ par exemple) en fonction des caractéristiques sociales des

individus.

9 Les musiciens du rang sont en bas de la hiérarchie de l'orchestre, derrière les solistes et les chefs de pupitre. train regularly in management and communication. The two first cases involve a local figure of professional integration in an entrepreneurial mode, breaking away from the romantic mythology of the pure and non-profit-oriented artist but in congruence with the neo-liberal conception of "creation" and "innovation."

In the face of the banality of the would-be exceptional artist's condition, feelings of failure and declining status are far from unanimous and unequivocal. These different possible attitudes (and one could probably find others) are mostly tied to inequalities in the social capacity to perceive the situation, especially one's own position in the field in relation to its most legitimate actors. For example, Bernard Lehmann showed the differences in the perception of the job among permanently salaried orchestral musicians in Paris (Lehmann 2002), including between members of the same instrumental section, who share the same working conditions and employment status. We thus find different views of the same objective position (rank and file orchestral musicians ${ }^{10}$, for example) based on the social characteristics of the individuals.

10 Rank and file musicians (in French musiciens du rang) are at the bottom of the orchestral hierarchy, below soloists and section leaders. 


\section{Conclusion}

On a vu dans les pages qui précèdent à quel point l'expression « artiste ordinaire » relève a priori de l'oxymore et conduit à analyser des situations qui semblent, en principe, incongrues alors qu'elles sont, en pratique, les plus courantes. Les articles du présent dossier apportent tous des éclairages différents et complémentaires sur des réalités à la fois banales et marginales dans des espaces sociaux très inégalitaires, concentrant la visibilité sur le petit nombre des «élus » parvenus au sommet de la pyramide professionnelle. Parce qu'elle représente l'envers de la condition d'artiste ordinaire qui nous intéresse ici - et qu'elle permet ainsi de la définir « en creux » - la situation de ces «élus » doit aussi être questionnée. La tentation de l'idéalisation est grande, en effet, lorsqu'on s'intéresse aux artistes les plus reconnus. Or, les univers artistiques n'étant jamais absolument autonomes, on peut se demander s'il existe réellement des artistes qui auraient, toujours et dans n'importe quelle cironstance, un rapport purement vocationnel à leur activité, qui ne dérogeraient jamais à l'idéal de « l'art pour l'art », etc. La notion d'artiste ordinaire permet ainsi de rappeler les aspects les plus prosaïques du travail artistique que même les « élus » ne peuvent jamais totalement ignorer (même l'artiste le plus reconnu doit, par exemple, se confronter d'une manière ou d'une autre à la question de la commercialisation de ses œuvres, ne serait-ce qu'en prenant connaissance des éléments transmis par son éditeur ou son agent à propos des chiffres de ses ventes, de sa couverture médiatique, etc.). II ne s'agit pas pour autant d'ignorer le fait que certains artistes, jugés « exceptionnels », sont dans des situations

\section{Conclusion}

The previous pages have shown to what extent the expression "ordinary artist" can be considered an oxymoron, which leads us to analyse situations that seem, in theory, incongruous even though they are, in practice, the most common. The dossier's articles give different and complementary insights into realities that are both banal and marginal in very inegalitarian social spaces, focusing visibility on the small number of "chosen ones" who have arrived at the summit of the professional pyramid. Since it represents the opposite condition to that of the ordinary artist on which we are focusing here-thereby allowing us to define it "implicitly"-the situation of these "chosen ones" must also be questioned. The temptation to idealize is indeed great, when one focuses on the most famous artists. Yet, artistic spheres never being completely autonomous, we may wonder if there really are artists who have, always and under any circumstances, a purely vocational relationship with their work, who never abandon the ideal of "art for the sake of art," etc. The notion of the ordinary artist recalls the most mundane aspects of artistic work that even the "chosen" can never totally ignore (even the most famous artist must, for example, grapple in one way or another with the question of the commercialisation of their work, if only in terms of finding out about information transmitted by a publisher or agent about sales numbers, media coverage, etc.). Nor should we ignore the fact that some artists who are considered "exceptional" are in objectively more enviable situations than others, and benefit from a material and human environment that allows them to guarantee and preserve much of this exceptional status. In other words, although the 
objectivement plus enviables que d'autres, et bénéficient d'un environnement matériel et humain à même de garantir et de préserver en très grande partie cette condition exceptionnelle. En d'autres termes, bien que la figure de l'artiste « extraordinaire » relève de la croyance et fasse apparaître, par contraste, les autres comme « ordinaires », ces derniers font face, de fait, à des conditions de travail objectives et subjectives beaucoup plus difficiles.

Enfin, au-delà des mondes de l'art, dans les articles qui suivent, le texte de Pierre Bataille participe d'une tentative d'élargir la focale à l'ensemble des producteurs de biens symboliques de diffusion restreinte (Bourdieu 1971). En s'intéressant aux modalités déclassées de l'insertion professionnelle des normaliens et notamment à la situation d'enseignants du secondaire diplômés d'une École normale supérieure, il montre combien il est fécond de concevoir un équivalent à l'« artiste ordinaire " dans les carrières intellectuelles, y compris dans un contexte de forte régulation institutionnelle, en exposant à la fois l'intérêt et les limites d'une telle transposition.

Si on étend davantage encore le questionnement, d'une part en s'intéressant à la production et à la circulation de biens symboliques de grande diffusion et, d'autre part, en prenant en compte la subjectivisation (voire la « sur-humanisation », Linhart 2015) du rapport au travail dans l'idéologie managériale contemporaine qui enjoint chacun à s'investir corps et âme dans son travail, on peut se demander si les cas présentés ici ne peuvent pas aussi constituer des modèles. La tertiarisation de l'économie et le développement du prolétariat des services figure of the "extraordinary" artist comes from a belief and makes others appear "ordinary" in comparison, the latter must face much more difficult subjective and objective working conditions.

Finally, beyond art worlds, in the following articles, Pierre Bataille's text contributes to an attempt to expand the focus onto a group of producers of symbolic goods of restricted diffusion (Bourdieu 1985). By taking an interest in the downgraded means of professional insertion for graduates of the École normale superieure, and notably those who teach in secondary education, he shows how fruitful it is to think of an equivalent to the "ordinary artist" in intellectual careers, including in the context of strict institutional regulations, by exposing both the interest and the limits of such a transposition.

Expanding the line of inquiry further, on one hand by exploring the production and circulation of widely diffused symbolic goods and, on the other hand, by considering the subjectivization (even "superhumanization," Linhart 2015) of attitudes to work within the contemporary managerial ideology which encourages each individual to invest their body and soul into their work, one can wonder whether the cases presented here may also be considered models. The tertiarization of the economy and the development of the service proletariat, but 
mais aussi l'essor du management horizontal et l'appel sans cesse renouvelé au «talent » et à la « créativité » des salariés conduisent à se demander si la situation paradoxale de l'artiste ordinaire n'est pas en train de devenir paradigmatique. De fait, l'enjeu ici est bien le déplacement (ou l'annulation) par l'idéologie managériale contemporaine de la frontière entre travail social (au sens marxien d'un travail dans lequel on s'accomplit en tant qu'humain) et travail aliéné. Lorsqu'il s'agit de faire de tout travailleur aliéné un travailleur de vocation cherchant à s'épanouir dans son travail, la contradiction intrinsèque à la figure de l'artiste ordinaire, le paradoxe de cette condition et l'instabilité permanente à laquelle il peut condamner, deviennent alors un paradigme généralisable à l'idéologie néomanagériale dans son ensemble. Dans les espaces du travail qualifié, les injonctions permanentes à se singulariser pour " sortir du lot », à " créer le désir », à innover, se « remettre en question », se « réinventer" (où l'on retrouve des proximités avec certaines théories de l'agentivité), produisent immanquablement, comme dans les mondes de l'art, une grande majorité de «perdants » : atomisés, menacés en permanence par le déclassement et contraints à une perpétuelle lutte individuelle pour leur survie économique et symbolique ${ }^{10}$

10 II faudrait aussi aborder ces mutations en ce qu'elles influent sur la mobilisation collective, notamment en étudiant l'engagement politique et syndical chez les artistes ordinaires et dans les mondes de l'art comme ont pu le faire Jérémy Sinigaglia pour les intermittents du spectacle (Sinigaglia 2007), Flora Bajard pour les céramistes (Bajard 2012) ou encore un dossie thématique de la revue Le Mouvement social paru en 2013 (Roueff et Sofio 2013) also the rise of horizontal management and an incessantly renewed call for the "talent" and "creativity" of wage earners, beg the question of whether the paradoxical situation of the ordinary artist is becoming a paradigm. In fact, the issue here is displacement (or annulment) by contemporary managerial ideology on the border between social work (in the Marxian sense of work that makes us human) and alienated work. When it comes to considering every alienated worker to be a vocational worker seeking self-fulfilment in his or her workthe intrinsic contradiction of the figure of the ordinary artistthe paradox of this condition, and the permanent instability to which it can condemn people, thus become a paradigm that can be generalized to include all neo-managerial ideology. In qualified work spaces, permanent injunctions to set oneself apart to "stand out from the crowd," "create desire," innovate, "keep challenging oneself," or "reinventing oneself" (where one can find similarities with some agentivity theories), undoubtedly produce, as in the art world, a large majority of "losers:" atomized, permanently threatened by loss of status and constraints for a perpetual individual fight for their economic and symbolic survival ${ }^{11}$.

11 It would also be necessary here to address these changes and what they mean for collective mobilization, notably by studying political and union engagement among ordinary artists and in the art world, as Jérémy Sinigaglia did for intermittent performing artists (Sinigaglia 2007), as Flora Bajard did for ceramicists (Bajard 2012), or even as shown in Roueff \& Sofio 2013. 
On trouvera dans ces derniers éléments une parenté avec des travaux bien connus datant du tournant du siècle et montrant comment l'intégration de la « critique artiste » par le capitalisme (Boltanski \& Chiapello 1999) produit un néolibéralisme auquel est fort bien ajustée la figure riscophile, presque libérale-libertaire, de l'artiste-entrepreneur (Menger 2002) comme protagoniste archétypique de la "société des individus " (Elias 1991). Ce dossier est surtout né de la volonté de donner une assise empirique robuste à l'étude de ces modalités si diverses de l'existence ordinaire en régime de singularité.

Marc Perrenoud

Université de Lausanne/Institut des sciences sociales, LACCUS (Laboratoire Capitalisme, Culture et Sociétés) https://www.unil.ch/laccus/fr/home.htm Université de Lorraine/2L2S (EA 3478), Laboratoire Lorrain de Sciences Sociales http://2|2s.univ-lorraine.fr/

\section{Références bibliographiques}

Azaïs Camille, BACHIR-Loopuyt Talia, SAINT-Germier Pierre (2010). « Du jazz aux mouvements sociaux : le répertoire en action. Entretien avec Howard Becker ». Tracés, $18: 223-236$

BAJARD Flora (2012). « Du travail d'atelier au collectif : I'inscription professionnelle ambivalente des céramistes-créateurs ». Sociologie de l'art, $\mathrm{n}^{\circ} 21(3)$ : 43-64.

BAJARD Flora \& PerRenoud Marc (2013). « "Ça n'a pas de prix.” Diversité des modes de rétribution des artisans d'art ". Sociétés contemporaines, $n^{\circ}$ 91(3) : 93-116.
These last elements have similarities with well-known works dating from the turn of the century that show how the integration of the "artistic critique" with capitalism (Boltanski \& Chiapello 2005) produces a neoliberalism to which the riskseeking, almost libertarian figure of the artist-entrepreneur (Menger 2002) is well adjusted, like the archetypal protagonist of the "society of individuals" (Elias 1987). This dossier was above all a product of the desire to give a robust, empirical foundation to the study of these very diverse modalities of ordinary existence within a world of that values uniqueness.

Marc Perrenoud

Université de Lausanne/Institut des sciences sociales, LACCUS (Laboratoire Capitalisme, Culture et Sociétés) https://www.unil.ch/laccus/fr/home.htm

Géraldine Bois Université de Lorraine/2L2S (EA 3478), Laboratoire Lorrain de Sciences Sociales http://2|2s.univ-lorraine.fr/

\section{References}

Azaïs Camille, Bachir-Loopuyt Talia, Saint-Germier Pierre (2010). "Du jazz aux mouvements sociaux: le répertoire en action. Entretien avec Howard Becker" (interview with Howard Becker). Tracés, 18: 223-236.

BAJARD Flora (2012). "Du travail d'atelier au collectif: l'inscription professionnelle ambivalente des céramistes-créateurs." Sociologie de l'art, 21(3): 43-64.

BAJARd Flora \& PerRenoud Marc (2013). "'Ça n'a pas de prix.' Diversité des modes de rétribution des artisans d'art." Sociétés contemporaines, 91(3): 93-116. 
BARTHES Roland (1957). Mythologies. Paris, Seuil.

BECKER Howard S. (1985) [1963]. Outsiders. Études de sociologie de la déviance. Traduit en français par Jean-Pierre Briand et Jean-Michel Chapoulie. Paris, Métailié.

BECKER Howard S. (1988). Les Mondes de l'art. Traduit en français par Jeanne Bouniort. Paris, Flammarion.

BECKER Howard S. (2013). "Quelques implications de l'équation Art $=$ Travail pour la sociologie de l'art ». Traduit en français par Arthur Zinn-Poget, Isabelle V. Zinn et Marc Perrenoud. In PerRenoud Marc (dir.), Les Mondes pluriels de Howard S. Becker. Paris, La Découverte : 117126.

Bols Géraldine (2011). "La notion d'illusio confrontée aux écrivains peu reconnus ». COnTEXTES, 9 [en ligne].

Boıs Géraldine (2013). «L'investissement des auteurs peu reconnus dans les tâches commerciales : une manière d'être écrivain ». In PerReNoud Marc (dir.), Travailler, produire, créer : entre l'art et le métier. Paris, L'Harmattan : 11-26.

BoIs Géraldine (2014). " Ancrage local et visibilité littéraire. Le cas des écrivains peu reconnus de la région Rhône-Alpes ». Ethnologie française, $44(4): 621-630$.

BoltANSKI Luc \& ChIAPELLo Ève (1999). Le Nouvel Esprit du capitalisme. Paris, Gallimard.

BOURDIEU Pierre (1971). «Le marché des biens symboliques ». L'Année sociologique, 22 : 49-126.

BOURDieu Pierre (1977). "La production de la croyance ». Actes de la recherche en sciences sociales, $13:$ 3-43.
BARTHES Roland (1972). Mythologies. English translation by Annette Lavers. New York, Farrar, Straus and Giroux.

BECKER Howard S. (1963). Outsiders. Studies in the Sociology of Deviance. New York, The Free Press of Glencoe.

BeCKER Howard S. (1982). Art Worlds. Berkeley, University of California Press.

BECKER Howard S. (2013). "Quelques implications de l'équation Art $=$ Travail pour la sociologie de l'art." In PeRRENOUd Marc (ed.), Les Mondes pluriels de Howard S. Becker. Paris, La Découverte: 117-126.

BoIs Géraldine (2011). "La notion d'illusio confrontée aux écrivains peu reconnus." COnTEXTES, 9 [on line].

BoIs Géraldine (2013). "L'investissement des auteurs peu reconnus dans les tâches commerciales: une manière d'être écrivain." In PerRenOud Marc (ed.). Travailler, produire, créer: entre l'art et le métier. Paris, L'Harmattan: 11-26.

BoIs Géraldine (2014). "Ancrage local et visibilité littéraire. Le cas des écrivains peu reconnus de la région Rhône-Alpes." Ethnologie française, 44(4): 621-630.

Boltanski Luc \& Chiapello Ève (2005). The New Spirit of Capitalism. English translation by Gregory Eliott. London/New York, Verso.

Bourdieu Pierre (1985). "The Market of Symbolic Goods." English translation by Rupert Swyer. Poetics, 14(1-2): 13-44.

Bourdieu Pierre (1980). "The Production of Belief." English translation by Richard Nice. Media, Culture \& Society, 2: 261-293. 
BOURDIEU Pierre (1979). La Distinction. Paris, Minuit.

BouRdieu Pierre (1994). Raisons pratiques. Paris, Minuit.

Bourdieu Pierre (1998) [1992]. Les Règles de l'art. Paris, Seuil.

BouRdieu Pierre (2003) [1997]. Méditations pascaliennes. Paris, Seuil.

Bureau Marie-Christine, Perrenoud Marc, Shapiro Roberta (dir.) (2009). L'Artiste pluriel. Démultiplier l'activité pour vivre de son art. Villeneuve d'Ascq, Presses Universitaires du Septentrion.

Buscatto Marie (2007). Femmes du jazz. Musicalités, féminités, marginalités. Paris, CNRS Éditions.

CARDon Vincent (2014). Emploi, vieillissement et retraite dans les métiers des spectacles, rapport pour le ministère de la Culture, DEPS.

CARDon Vincent \& PILMIS Olivier (2013). « Des projets à la carrière. Les artistes interprètes et leurs anticipations des contreparties du travail, une perspective biographique ». Sociétés contemporaines, 91: 43-65.

DeNIS Benoît (2010). «La consécration. Quelques notes introductives ». CONTEXTES, 7.

DuBols Jacques (1978). L'Institution de la littérature. Introduction à une sociologie. Bruxelles, Bernand Natnan/Éditions Labor.

DuboIs Vincent, MÉon Jean-Mathieu, PIerRu Emmanuel (2009). Les Mondes de l'harmonie. Enquête sur une pratique musicale amateur. Paris, La Dispute.
BouRdieu Pierre (1984). Distinction. English translation by Richard Nice. Cambridge, Harvard University Press.

Bourdieu Pierre (1998). Practical Reason. English translation by Randal Johnson and others. Stanford, Stanford University Press.

Bourdieu Pierre (1995). The Rules of Art. English translation by Susan Emanuel. Stanford, Stanford University Press.

Bourdieu Pierre (2000). Pascalian Meditations. English translation by Richard Nice. Stanford, Stanford University Press.

Bureau Marie-Christine, Perrenoud Marc, Shapiro Roberta (eds.) (2009). L'Artiste pluriel. Démultiplier l'activité pour vivre de son art. Villeneuve d'Ascq, Presses Universitaires du Septentrion.

Buscatto Marie (2007). Femmes du jazz. Musicalités, féminités, marginalités. Paris, CNRS Éditions.

Cardon Vincent (2014). Emploi, vieillissement et retraite dans les métiers des spectacles, rapport pour le ministère de la Culture, DEPS.

CARDON Vincent \& PILmis Olivier (2013). "Des projets à la carrière. Les artistes interprètes et leurs anticipations des contreparties du travail, une perspective biographique." Sociétés contemporaines, 91: 43-65.

DENIS Benoît (2010). "La consécration. Quelques notes introductives." CONTEXTES, 7.

DuBoıs Jacques (1978). L'Institution de la littérature. Introduction à une sociologie. Bruxelles, Bernand Natnan/Éditions Labor.

Dubols Vincent, MÉon Jean-Mathieu, Pierru Emmanuel (2009). Les Mondes de l'harmonie. Enquête sur une pratique musicale amateur. Paris, La Dispute. 
ELIAS Norbert (1991) [1987]. La Société des individus. Traduit en français par Jeanne Etoré. Paris, Fayard.

FAULKNER Robert R. \& BeCKeR Howard S. (2011). Qu'est-ce qu'on joue maintenant ? Le répertoire de jazz en action. Traduit en français par Bruno Gendre. Paris, La Découverte.

FREIDSON Eliot (1986). « Les professions artistiques comme défi à l'analyse sociologique ». Traduit en français par Jean-Claude Chamboredon et Pierre-Michel Menger. Sociologie du travail, 27(3) : 431-443.

HeINICH Nathalie (1993). Du peintre à l'artiste. Paris, Minuit.

HEINICH Nathalie (1995). “ Façons d'“être” écrivain. L'identité professionnelle en régime de singularité ". Revue française de sociologie, 36(3) : 499-524.

JeAnPIerRe Laurent \& RouefF Olivier (dir.) (2014). La Culture et ses intermédiaires. Dans les arts, le numérique et les industries créatives. Paris, Archives contemporaines.

KaTz Serge (2015). Comédiens par intermittence. Le métier à l'épreuve de la disqualification professionnelle. Paris, Presses du Châtelet.

LAHIRE Bernard (avec la collaboration de Géraldine BoIs) (2006). La Condition littéraire. Paris, La Découverte.

Lehmann Bernard (2002). L'Orchestre dans tous ses éclats. Paris, La Découverte.

LINHART Danièle (2015). La Comédie humaine du travail. De la déshumanisation taylorienne à la sur-humanisation managériale. Paris, Érès.
ELIAS Norbert (1991) [1987]. The Society of Individuals. Oxford, Basil Blackwell.

FAULKNeR Robert R. \& BeCKen Howard S. (2009). Do You Know...? Chicago, The University of Chicago Press.

FREIDSON Eliot (1986). "Les professions artistiques comme défi à l'analyse sociologique." Sociologie du travail, 27(3): 431-443.

\section{HEINICH Nathalie (1993). Du peintre à l'artiste. Paris, Minuit.}

HEINICH Nathalie (1995). "Façons d"être'écrivain. L'identité professionnelle en régime de singularité." Revue française de sociologie, 36(3): 499-524.

JeAnPIERRE Laurent \& RouefF Olivier (eds.) (2014). La Culture et ses intermédiaires. Dans les arts, le numérique et les industries créatives. Paris, Archives contemporaines.

Katz Serge (2015). Comédiens par intermittence. Le métier à l'épreuve de la disqualification professionnelle. Paris, Presses du Châtelet.

LAHIRE Bernard (with Géraldine BoIs) (2006). La Condition littéraire. Paris, La Découverte.

Lehmann Bernard (2002). L'Orchestre dans tous ses éclats. Paris, La Découverte.

LINHART Danièle (2015). La Comédie humaine du travail. De la déshumanisation taylorienne à la sur-humanisation managériale. Paris, Érès. 
Lizé Wenceslas, NAUdiER Delphine, Sofio Séverine (dir.) (2014). Les Stratèges de la notoriété. Intermédiaires et consécration dans les univers artistiques. Paris, Archives contemporaines.

Menger Pierre-Michel (2002). Portrait de l'artiste en travailleur, Paris, Seuil.

Menger Pierre-Michel (2013). « La dramaturgie sociale du travail. Une conception interactionniste de la stratification ». In PERRENOUd Marc (dir.), Les Mondes pluriels de Howard S. Becker. Paris, La Découverte : 207237.

Moulin Raymonde (1967). Le Marché de la peinture en France. Paris, Minuit.

Moulin Raymonde, PAsseron Jean-Claude, PAsquier Dominique, PortoVASQUEZ Fernando (1985). Les Artistes. Essai de morphologie sociale. Paris, La Documentation française.

PASQUIER Domminique (1983). « Carrières de femmes : l'art et la manière ». Sociologie du travail, 4 : 418-431.

Perrenoud Marc (2006). " Jouer "le jazz" : où ? comment ? Approche ethnographique et distinction des dispositifs de jeu ». Sociologie de l'art $8: 25-42$.

Perrenoud Marc (2007). Les Musicos. Enquête sur des musiciens ordinaires. Paris, La Découverte.

Perrenoud Marc (2008). « Les artisans de la "gentrification rurale" : trois manières d'être maçon dans les Corbières ". Sociétés contemporaines, $71: 95-115$.

Perrenoud Marc (2009). « Les formes de la démultiplication dans la carrière des musicos ». In Bureau Marie-Christine, Perrenoud Marc,
LIZÉ Wenceslas, NAUdiER Delphine, Sofio Séverine (eds.) (2014). Les Stratèges de la notoriété. Intermédiaires et consécration dans les univers artistiques. Paris, Archives contemporaines.

Menger Pierre-Michel (2002). Portrait de l'artiste en travailleur, Paris, Seuil.

Menger Pierre-Michel (2013). "La dramaturgie sociale du travail. Une conception interactionniste de la stratification." In PERRENOUd Marc (ed.) Les Mondes pluriels de Howard S. Becker. Paris, La Découverte: $207-$ 237.

Moulin Raymonde (1967). Le Marché de la peinture en France. Paris, Minuit.

Moulin Raymonde, Passeron Jean-Claude, Pasquier Dominique, PortoVASQUEZ Fernando (1985). Les Artistes. Essai de morphologie sociale. Paris, La Documentation française.

PASQUIER Domminique (1983). "Carrières de femmes: l'art et la manière." Sociologie du travail, 4 : 418-431.

Perrenoud Marc (2006). "Jouer 'le jazz': où? comment? Approche ethnographique et distinction des dispositifs de jeu." Sociologie de l'art, 8: $25-42$.

Perrenoud Marc (2007). Les Musicos. Enquête sur des musiciens ordinaires. Paris, La Découverte.

Perrenoud Marc (2008). "Les artisans de la 'gentrification rurale': trois manières d'être maçon dans les Hautes-Corbières." Sociétés contemporaines, 71: 95-115.

Perrenoud Marc (2009). "Les formes de la démultiplication dans la carrière des musicos." In Bureau Marie-Christine, Perrenoud Marc, 
SHAPIRO Roberta (dir.), L'Artiste pluriel. Démultiplier l'activité pour vivre de son art. Villeneuve d'Ascq, Presses Universitaires du Septentrion : 51-68.

Perrenoud Marc (2013). " "Musicien de jazz" : une catégorie familière à l'épreuve du terrain ». In Howard Becker et les mondes de l'art. Paris, CNRS/Presses de l'École polytechnique : 27-34.

Perrenoud Marc (2015). "Économie des biens symboliques et dramaturgie sociale du travail ». In QuıJoux Maxime (dir.), Bourdieu et le travail. Rennes, Presses Universitaires de Rennes : 193-204.

PolıK Claude (2006). Aux frontières du champ littéraire. Sociologie des écrivains amateurs. Paris, Economica.

RanNou Janine \& RohaRIK Ionela (2006). Les Danseurs. Un métier d'engagement. Paris, Ministère de la Culture/DEPS.

RAVET Hyacinthe (2003). « Professionnalisation féminine et féminisation d'une profession : les artistes interprètes de musique ». Travail, genre et sociétés, $9: 173-195$

RoIGT Jean \& KLEIN René (2002). Contribution à la reflexion des partenaires sociaux sur les origines des écarts entre les différentes sources statistiques sur les artistes et techniciens intermittents du spectacle, et les aménagements à apporter au fonctionnement des annexes 8 et 10 du régime d'assurance-chômage, rapport IGAS-IGAC.

ROUEFF Olivier \& SOFIO Séverine (2013). «Intermédiaires culturels et mobilisations dans les mondes de l'art », Le Mouvement social, $243: 3-7$.

Schotré Manuel (2012). La Construction du «talent ». Sociologie de la domination des coureurs marocains. Paris, Raisons d'agir.
SHAPIRO Roberta (eds.), L'Artiste pluriel. Démultiplier l'activité pour vivre de son art. Villeneuve d'Ascq, Presses Universitaires du Septentrion: 51 68.

Perrenoud Marc (2013). "Musicien de jazz': une catégorie familière à l'épreuve du terrain." In Howard Becker et les mondes de l'art. Paris, CNRS/Presses de l'École polytechnique: 27-34.

Perrenoud Marc (2015). "Économie des biens symboliques et dramaturgie sociale du travail." In Quisoux Maxime (ed.), Bourdieu et le travail. Rennes, Presses Universitaires de Rennes: 193-204.

PolIAK Claude (2006). Aux frontières du champ littéraire. Sociologie des écrivains amateurs. Paris, Economica.

Rannou Janine \& RohaRIK Ionela (2006). Les Danseurs. Un métier d'engagement. Paris, Ministère de la Culture/DEPS.

RAVET Hyacinthe (2003). "Professionnalisation féminine et féminisation d'une profession: les artistes interprètes de musique." Travail, genre et sociétés, 9: 173-195.

ROIGT Jean \& KLEIN René (2002). Contribution à la reflexion des partenaires sociaux sur les origines des écarts entre les différentes sources statistiques sur les artistes et techniciens intermittents du spectacle, et les aménagements à apporter au fonctionnement des annexes 8 et 10 du régime d'assurance-chômage, rapport IGAS-IGAC.

ROUEFF Olivier \& SOFIO Séverine (2013). "Intermédiaires culturels et mobilisations dans les mondes de l'art." Le Mouvement social, 243: 3-7.

SCHOTTÉ Manuel (2012). La Construction du "talent." Sociologie de la domination des coureurs marocains. Paris, Raisons d'agir. 
SINGLY François (DE) (1986). «Artistes en vue ». Revue française de sociologie, $27(3): 531-543$.

SINIGAGLIA Jérémy (2007). " Le mouvement des intermittents du spectacle : entre précarité démobilisatrice et précaires mobilisateurs ». Sociétés contemporaines, $65:$ 27-54.

Soflo Séverine (2016). Artistes femmes. La parenthèse enchantée. XVIII$X I X^{e}$ siècles. Paris, CNRS Éditions.

SORIGNET Pierre-Emmanuel (2004). « Être danseuse contemporaine : une carrière "corps et âme" », Travail, genre et sociétés, 12 : 33-53.

SoRIGNET Pierre-Emmanuel (2010). Danser. Enquête dans les coulisses d'une vocation. Paris, La Découverte.

WHITE Harrison C. \& WHITE Cynthia A. (1991) [1965]. La Carrière des peintres au XIXe siècle : du système académique au marché des impressionnistes. Traduit en français par Antoine Jaccottet. Paris, Flammarion.
SINGLY François (DE) (1986). "Artistes en vue." Revue française de sociologie, $27(3)$ : $531-543$

SINIGAGLIA Jérémy (2007). "Le mouvement des intermittents du spectacle: entre précarité démobilisatrice et précaires mobilisateurs." Sociétés contemporaines, 65: 27-54.

Soflo Séverine (2016). Artistes femmes. La parenthèse enchantée. XVIII $X I X^{e}$ siècles. Paris, CNRS Éditions.

SORIGNET Pierre-Emmanuel (2004). "Être danseuse contemporaine: une carrière 'corps et âme'." Travail, genre et sociétés, 12: 33-53.

SORIGNET Pierre-Emmanuel (2010). Danser. Enquête dans les coulisses d'une vocation. Paris, La Découverte.

WHITE Harrison C. \& WHITE Cynthia A. (1965). Canvases and Careers: Institutional Change in the French Painting World. New York, John Wiley \& Sons. 